\title{
MARX E O SUJEITO DE DIREITO? A LEITURA DOS GRUNDRISSE DIANTE DA LEITURA PACHUKANIANA DO AUTOR DE O CAPITAL
}

Vitor Sartori ${ }^{1}$

\section{RESUMO}

A partir da análise imanente dos Grundrisse, abordaremos o tratamento marxiano do Direito ao se ter em conta as categorias pessoa e sujeito. Pretendemos demonstrar que o tratamento marxiano da questão ultrapassa aquele de Pachukanis, autor mais renomado da crítica marxista ao Direito. Mesmo que o autor soviético acerte em pontos-chave de sua análise, ele vem a elaborar com menos cuidado que deveria a correlação entre a forma mercadoria e outras formas sociais, como o dinheiro e o capital. Tem-se, em Marx, não só uma relação entre troca mercantil e forma jurídica, mas uma análise do papel ativo do Direito na medida em que sua autonomização passa pela forma dinheiro e redunda na possibilidade da separação absoluta entre condições materiais de produção e a propriedade.

Palavras-Chave: Marx, Grundrisse, Direito, Pachukanis, sujeito

¿MARX Y EL SUJETO DEL DERECHO? LA LECTURA GRUNDRISSE ANTES DE LA LECTURA PACHUKANA DEL AUTOR DE LA CAPITAL

\section{RESUMEN}

Con base en el análisis inmanente de Grundrisse, abordaremos el tratamiento marxista del Derecho teniendo en cuenta las categorías de persona y sujeto. Pretendemos demostrar que el tratamiento marxista de la cuestión va más allá del de Pachukanis, el autor más renombrado de la crítica marxista del Derecho. Incluso si el autor soviético da con puntos

1 Vitor Bartoletti Sartori, Universidade Federal de Minas Gerais, Belo Horizonte, Minas Gerais, Brasil. Email: vitorbsartori@gmail.com. ORCID: https://orcid.org/0000-0001-9570-9968. 
clave en su análisis, llega a elaborar con menos cuidado del que debería la correlación entre la forma mercancía y otras formas sociales, como el dinero y el capital. En Marx, no solo hay una relación entre el intercambio mercantil y la forma jurídica, sino un análisis del papel activo del derecho a medida que su autonomía se convierte en dinero y da como resultado la posibilidad de una separación absoluta entre las condiciones materiales de producción y propiedad.

Palabras clave: Marx, Grundrisse, Derecho, Pachukanis, sujeto

\section{MARX AND THE SUBJECT OF RIGHTS? GRUNDRISSE AND THE PACHUKANIAN INTERPRETATION OF THE CAPITAL AUTHOR}

\section{ABSTRACT}

Based on Grundrisse's immanent analysis, we will see the Marxian treatment of law and verify its approach to the categories of person and subject. It aims to demonstrate that the Marxian treatment of the issue goes beyond that of Pachukanis. Even if the Soviet author comprehends very well certain aspects of Marx, he comes up with them with less care that must be correlated between the form of commodities and other social forms, such as money and capital. It is not a relation between mercantile exchange and legal form, but an analysis of the active role of Right and its autonomy that must be explained. It goes through the money form and results in the possibility of absolute separation between the conditions of material production and property.

Keywords: Marx, Grundrisse, Law, Pachukanis, Subject

\section{INTRODUÇÃO}

No Brasil, a existência de uma crítica marxista ao Direito rigorosa, em grande parte, deve-se à leitura pachukaniana, capitaneada por Márcio Naves. Os méritos do filósofo brasileiro não são poucos. Tem-se à disposição seu estudo sério sobre o jurista soviético a partir da língua russa (Cf. NAVES, 2000), bem como uma fundamentação sofisticada da leitura da obra marxiana, assentada no marxismo althusseriano. (Cf. NAVES, 2014) Pode-se dizer 
que, por aqui, Naves abriu um importante espaço para o desenvolvimento de uma tradição crítica ao Direito, em que se inserem nomes como Alysson Mascaro, Silvio Luís de Almeida, entre outros. E, é preciso que se diga: em meio a tal tradição, mesmo que a diferença entre os posicionamentos de Mascaro (2012), Almeida e autores como Celso Kashiura Jr. (2009, 2014) seja marcante por vezes, há de se perceber que a base da visão destes marxistas está tanto na leitura da obra de Pachukanis (2017) quanto na correlação entre o sujeito de direito e a forma mercantil, desenvolvida na obra Teoria geral do Direito e o marxismo. ${ }^{2}$

Tal interpretação é um ponto de partida praticamente consolidado nos estudos marxistas brasileiros sobre o Direito. E isto acontece porque, segundo tal leitura, como disse Naves:

Pachukanis, rigorosamente, retorna a Marx, isto é, não apenas às referências ao Direito encontradas em $O$ capital - e não seria exagero dizer que ele é o primeiro que verdadeiramente as lê - mas, principalmente, ele retorna à inspiração original de Marx, ao recuperar o método marxiano. (NAVES, 2000, p. 16)

O pressuposto central desta visão seria a correção da leitura pachukaniana de Marx. Isto se dá na medida em que se supõe que a concepção pachukaniana sobre o tema é acertada, tanto quanto ao método de Marx, quanto ao se trazer uma leitura correta da obra magna do autor alemão. Noutro lugar, mostrou-se que pode haver críticas ao ponto de partida do autor soviético, tanto ao analisar a forma jurídica (Cf. SARTORI, 2020) quanto no que diz respeito à correlação entre a noção marxiana de pessoa e a categoria - central a Pachukanis - sujeito de direito. (Cf. SARTORI, 2019 a) Aqui, procuraremos demonstrar como que, também nos Grundrisse, obra marxiana que o autor soviético não pode ter acesso na íntegra, é possível enxergar mais meandros no tratamento do Direito.

Teve-se, na mencionada tradição, como central a análise do principal texto abordado pelo autor de Teoria geral do Direito e o marxismo, 0 capital. Essencialmente a partir do

\footnotetext{
${ }^{2}$ Diz Pachukanis que "o homem se transforma em sujeito de direito por força daquela mesma necessidade em virtude da qual o produto natural se transforma em uma mercadoria dotada da enigmática qualidade do valor." (PACHUKANIS, 2017, p. 83)
} 
primeiro parágrafo do capítulo II deste livro ${ }^{3}$, colocou-se como ponto de partida essencial ao marxismo a relação entre forma jurídica, forma mercantil e a conformação da relação-capital. (Cf. SARTORI, 2020) Sujeito de direito, circulação mercantil e forma jurídica seriam o início do debate marxista e de Marx sobre o Direito. Intentaremos demonstrar que este aspecto pode ser considerado, até certo ponto, importante para o autor de $O$ capital. Porém, seria preciso ir bastante além, já em Marx.

Aqui não poderemos entrar nas vicissitudes da leitura pachukaniana de $O$ capital. Porém, pretendemos trazer à tona uma obra de Marx em que a noção de pessoa e de sujeito aparecem correlacionadas ao Direito de modo mais direto que no principal texto marxiano; analisaremos os Grundrisse, texto fundamental para que se pudesse pensar a arquitetura de sua obra magna e para que organizasse suas ideias. Ali, de certo modo, o modo de exposição e o modo de pesquisa do autor ainda não estão claramente separados; e, assim, alguns passos marxianos de $O$ capital - que não estão explicitados noutro local - podem ser vistos em desenvolvimento nestes rascunhos escritos em 1857.

Se é certo que a grande obra de Marx continua sendo $O$ capital, igualmente verdadeiro é que esta obra pode ser bem compreendida ao passar pelos Grundrisse, como já comprovou Rosdolsky. (2001) Ela, de certo modo, pode ser vista como um laboratório de $O$ capital. (Cf. GRESPAN, 2019) E, assim, uma leitura atenta dela pode ser de grande valia, também, para a crítica marxista ao Direito, que partiu principalmente do livro I do principal texto marxiano de crítica à economia política.

\footnotetext{
3 Veja-se a passagem: "as mercadorias não podem por si mesmas ir ao mercado e se trocar. Devemos, portanto, voltar a vista para seus guardiões, os possuidores de mercadorias. As mercadorias são coisas e, consequentemente, não opõem resistência ao homem. Se elas não se submetem a ele de boa vontade, ele pode usar a violência, em outras palavras, tomá-las. Para que essas coisas se refiram umas às outras como mercadorias, é necessário que os seus guardiões se relacionem entre si como pessoas, cuja vontade reside nessas coisas, de tal modo que um, somente de acordo com a vontade do outro, portanto, apenas mediante um ato de vontade comum a ambos, se aproprie da mercadoria alheia enquanto aliena a própria. Eles devem, portanto, reconhecer-se reciprocamente como proprietários privados. Essa relação jurídica, cuja forma é o contrato, desenvolvida legalmente ou não, é uma relação de vontade, em que se reflete uma relação econômica. O conteúdo dessa relação jurídica ou de vontade é dado por meio da relação econômica mesma." (MARX, 1996 a, p. 79) Para uma análise cuidadosa dela, Cf. SARTORI, 2019 a. Para uma crítica à relação entre forma jurídica e mercantil a partir de tal passagem, Cf. PAÇO CUNHA, 2014, 2015.
} 
Neste artigo, a partir de uma leitura imanente ${ }^{4}$ dos Grundrisse, de Karl Marx, pretendemos analisar a correlação entre a esfera jurídica e as noções de sujeito e de pessoa, utilizadas pelo autor tanto em $O$ capital - livro de que partem Pachukanis e a tradição brasileira de crítica marxista ao Direito - quanto em outros textos, como o que aqui trataremos. A partir da relação entre sujeito e Direito nesta obra marxiana intentamos demonstrar que talvez seja possível confrontar aspectos específicos da concepção hegemônica na crítica marxista ao Direito, e da leitura pachukaniana que lhe dá base, ao mesmo tempo em que se reconhece os méritos desta tradição. Ou seja, a partir da explicitação do texto do próprio Marx, incorremos na explicitação da articulação categorial de seu pensamento, sem que se tenha imputações por parte do intérprete diante das determinações do próprio texto. Acreditamos que este seja um primeiro passo importante para o desenvolvimento da crítica marxista, no caso, relacionada à apreensão da especificidade e da função do Direito na sociedade.

\section{PRODUÇÃO CAPITALISTA, VONTADE LIVRE, SUJEITO E DETERMINAÇÃO DAS FORMAS ECONÔMICAS}

A leitura mais difundida na crítica marxista ao Direito parte de Pachukanis, que, no começo do século XX, foi um dos poucos autores a dar a devida importância à lei do valor. Na esteira de Rubin (1987), o fetichismo da mercadoria veio a adquirir um papel de grande relevo na teorização do autor. ${ }^{5}$ Isto precisa ser analisado, já que o solo no qual se coloca uma categoria muito importante para o Direito, a vontade livre, é aquele da circulação de mercadorias. (Cf. SARTORI, 2019 a) Tal categoria, inclusive, aparece correlacionada aos Direitos do homem e, como disse Marx em uma passagem famosa: “a esfera da circulação ou

\footnotetext{
4 Como diz Chasin: "tal análise, no melhor da tradição reflexiva, encara o texto - a formação ideal - em sua consistência autosignificativa, aí compreendida toda a grade de vetores que o conformam, tanto positivos como negativos: o conjunto de suas afirmações, conexões e suficiências, como as eventuais lacunas e incongruências que o perfaçam. Configuração esta que em si é autônoma em relação aos modos pelos quais é encarada, de frente ou por vieses, iluminada ou obscurecida no movimento de produção do para-nós que é elaborado pelo investigador, já que, no extremo e por absurdo, mesmo se todo o observador fosse incapaz de entender o sentido das coisas e dos textos, os nexos ou significados destes não deixariam, por isso, de existir [...]". (CHASIN, 2009, p. 26)

${ }^{5}$ Diz Pachukanis que "o fetichismo da mercadoria se completa com o fetichismo jurídico." (PACHUKANIS, 2017, p. 124)
} 
do intercâmbio de mercadorias, dentro de cujos limites se movimentam compra e venda de força de trabalho, era de fato um verdadeiro éden dos direitos naturais do homem." (MARX, 1996 b, p. 144) ${ }^{6}$ Ou seja, não há como deixar de se relacionar a circulação de mercadorias com o Direito, como bem apontou Pachukanis. (2017)

Daí decorre também que a atomização dos proprietários privados, bem como a circulação de mercadorias efetivamente estão ligadas às relações jurídicas na obra de Marx, como apontou Pachukanis ao analisar a correlação entre forma mercantil e igualdade jurídica. (Cf. SARTORI, 2015) Porém, é importante que nos atentemos ao modo pelo qual isto se dá na obra marxiana ao levar em consideração o desenvolvimento das formas econômicas como mercadoria, dinheiro e capital. Se na leitura do autor da Teoria geral do Direito e o marxismo Marx faz isto ao trazer à tona a categoria jurídica de sujeito, é preciso que analisemos até que ponto isto efetivamente ocorre no texto do autor alemão. Neste sentido, vale analisar não só $O$ capital, de que parte a análise pachukaniana; nos Grundrisse, ao contrário do que se dá na obra magna de nosso autor, a categoria sujeito aparece correlacionada ao Direito por Marx, não sendo necessário qualquer salto da categoria pessoa à categoria sujeito. (Cf. SARTORI, 2019 a) ${ }^{7}$ Ou seja, em uma primeira mirada, a teoria pachukaniana é ratificada de modo cabal pela obra que o autor soviético não pode ler, os Grundrisse.

\footnotetext{
${ }^{6}$ A citação continua da seguinte maneira: "o que aqui reina é unicamente Liberdade, Igualdade, Propriedade e Bentham. Liberdade! Pois comprador e vendedor de uma mercadoria, por exemplo, da força de trabalho, são determinados apenas por sua livre-vontade. Contratam como pessoas livres, juridicamente iguais. 0 contrato é o resultado final, no qual suas vontades se dão uma expressão jurídica em comum. Igualdade! Pois eles se relacionam um com o outro apenas como possuidores de mercadorias e trocam equivalente por equivalente. Propriedade! Pois cada um dispõe apenas sobre o seu. Bentham! Pois cada um dos dois só cuida de si mesmo. 0 único poder que os junta e leva a um relacionamento é o proveito próprio, a vantagem particular, os seus interesses privados." (MARX, 1996, p. 144)

${ }^{7}$ Marx diz sobre o valor, o dinheiro e a mercadoria em $O$ capital, sem qualquer referência ao Direito: "as formas autônomas, as formas dinheiro, que o valor das mercadorias assume na circulação simples mediam apenas o intercâmbio de mercadorias e desaparecem no resultado final do movimento. Na circulação D - M - D, pelo contrário, ambos, mercadoria e dinheiro, funcionam apenas como modos diferentes de existência do próprio valor, o dinheiro o seu modo geral, a mercadoria o seu modo particular, por assim dizer apenas camuflado, de existência. Ele passa continuamente de uma forma para outra, sem perder-se nesse movimento, e assim se transforma num sujeito automático. Fixadas as formas particulares de aparição, que o valor que se valoriza assume alternativamente no ciclo de sua vida, então se obtêm as explicações: capital é dinheiro, capital é mercadoria. De fato, porém, o valor se torna aqui o sujeito de um processo em que ele, por meio de uma mudança constante das formas de dinheiro e mercadoria, modifica a sua própria grandeza, enquanto mais-valia se repele de si mesmo, enquanto valor original, se autovaloriza. Pois o movimento, pelo qual ele adiciona mais-
} 
Mesmo que tal obra tenha sido publicada posteriormente ao assassinato do jurista soviético nos famigerados processos de Moscou, ela, de certo modo, coroaria a crítica marxista de Pachukanis.

Comecemos a análise do texto marxiano propriamente dito, pois.

De início, há de se notar que a equação entre liberdade, igualdade e troca mercantil, destacada por Pachukanis, está nos Grundrisse também, em que se diz sobre a economia clássica e os indivíduos que: a produção "constitui o motivo para a integração desses indivíduos, para a sua relação social como trocadores, relação em que são pressupostos e se afirmam como iguais, à determinação da igualdade soma-se a da liberdade." (MARX, 2011, p. 296) E, assim, tanto a oposição entre interesses privados dos indivíduos quanto sua integração no mercado são determinações de reflexão.

Como trocadores, os indivíduos são iguais e livres; eles estão envolvidas no incremento das forças produtivas - e, portanto, de suas capacidades e potencialidades ${ }^{8}$ - ao mesmo tempo em que a forma pela qual se dá o reconhecimento destas pessoas seja bastante limitada: “ainda que o indivíduo A sinta necessidade da mercadoria do indivíduo B, não se apodera dela pela força, nem vice-versa, mas reconhecem-se mutuamente como proprietários, como pessoas cuja vontade impregna suas mercadorias." (MARX, 2011, p. 296) Os indivíduos, portanto, reconhecem-se como proprietários privados de mercadorias; reconhecem-se como pessoas na medida em que a suas vontades impregnam as mercadorias. Se é verdade que a força não seja a mediação essencial no ato de troca, não deixa de haver sujeição dos indivíduos a uma potência estranhada, que faz com que se tenha o domínio das coisas sobre os homens: a vontade livre impregna as mercadorias; os indivíduos se reconhecem somente por meio destas. E, assim, são essencialmente proprietários de mercadorias nesta esfera.

valia, é seu próprio movimento, sua valorização, portanto autovalorização. Ele recebeu a qualidade oculta de gerar valor porque ele é valor. Ele pare filhotes vivos ou ao menos põe ovos de ouro." (MARX, 1996 a, p. 273-274) ${ }^{8}$ Dizem Marx e Engels na Ideologia alemã sobre as forças produtivas: "a apropriação dessas forças não é em si mesma nada mais do que o desenvolvimento das capacidades individuais correspondentes aos instrumentos materiais de produção. A apropriação de uma totalidade de instrumentos de produção é, precisamente por isso, o desenvolvimento de uma totalidade de capacidades nos próprios indivíduos.” (MARX; ENGELS, 2007, p. 73) 
Isto, claro, pressupõe determinada configuração da esfera da produção. Tem-se, assim, que, "antes de tudo, o primeiro pressuposto é que a relação de escravidão ou de servidão seja abolida. A capacidade de trabalho viva pertence a si mesma e dispõe, por meio da troca, da manifestação de sua própria energia." (MARX, 2011, p. 617) Ou seja, subjacente à circulação mercantil, em que os indivíduos se reconhecem como proprietários iguais e dotados de vontade livre, tem-se a conformação da relação-capital. E, desta maneira, a determinação desta forma de reconhecimento está ancorada na produção capitalista de mercadorias, que, a rigor, ultrapassa a relação jurídica. Continua Marx:

As duas partes se defrontam como pessoas. Formalmente, sua relação é a relação igual e livre de trocadores. Que essa forma seja aparência, e aparência enganosa, apresentase, considerada a relação jurídica, como algo situado fora desta. 0 que o trabalhador livre vende é sempre só uma medida determinada, particular, de manifestação de energia; acima de toda manifestação particular está a capacidade de trabalho como totalidade. 0 trabalhador vende a manifestação de força particular a um capitalista particular, com quem se defronta como indivíduo independente. É claro que essa não é a sua relação com a existência do capital como capital, i.e., com a classe dos capitalistas. Somente desse modo deixa-se, no que diz respeito à pessoa singular efetiva, um amplo espaço de escolha, de arbítrio e, em consequência, de liberdade formal. $\mathrm{Na}$ relação escravista, o trabalhador pertence ao proprietário singular, particular, de quem é máquina de trabalho. Como totalidade de manifestação de energia, como capacidade de trabalho, o trabalhador é uma coisa pertencente a outrem e, por conseguinte, não se comporta como sujeito em relação à sua manifestação de energia particular ou à ação viva do trabalho. Na relação de servidão, o trabalhador aparece como momento da própria propriedade fundiária, é acessório da terra, exatamente como os animais de tração. Na relação escravista, o trabalhador nada mais é do que máquina de trabalho viva que, por isso, tem valor para outros ou, mais precisamente, é um valor. Em sua própria totalidade, a capacidade de trabalho aparece diante do trabalhador livre como sua propriedade, como um dos momentos sobre o qual ele exerce o domínio como sujeito e que ele conserva ao alienar. Desenvolver isso mais tarde, no trabalho assalariado." (MARX, 2011, p. 617-618)

O reconhecimento como proprietários, bem como a representação dos indivíduos como pessoas, mesmo que apareça como algo natural, decorre da correlação entre as esferas 
da economia capitalista, a saber, produção, distribuição, circulação, troca e consumo. (Cf. SARTORI, 2019 a) Ou seja, o essencial para a compressão da categoria pessoa está na correlação entre as formas econômicas e o modo pelo qual a individualidade se apresente aos portadores práticos das relações econômicas.

De início, portanto, parece que o central à compreensão da categoria pessoa não está propriamente no Direito. Este último, porém, naturaliza o modo de representação e de apresentação (Cf. GRESPAN, 2019) da igualdade e da liberdade dos trocadores, como bem apontou Pachukanis (2017); A partir da esfera jurídica, as formas econômicas parecem estar situadas fora da relação jurídica enquanto, em verdade, conferem a esta relação seu conteúdo. No que se tem uma questão importante: a venda e alienação (Veräusserung) ${ }^{9}$ da capacidade de trabalho (chamada por Marx, em $O$ capital, de força de trabalho) apresenta-se ao trabalhador como uma coisa, que, como indivíduo independente, poderia vender ao capitalista; ou seja, o modo de representação efetivo na esfera da circulação mercantil supõe o modo de produção capitalista como um dado natural. E, também por isto, a caracterização dos indivíduos como pessoas remete a algo que certamente passa pelas relações jurídicas, mas que decorre da conformação objetiva das relações de produção. A oposição entre coisas e pessoas tende a ser essencial nesta análise, que é levada a cabo por Marx na medida em que ele busca compreender a relação entre a produção e a circulação. (Cf. SARTORI, 2019 a)

Tanto é assim que Marx logo diferencia tal situação, que não opera pela violência direta, mas que é encaminhada pelas relações jurídicas e pela livre vontade, daquela da escravidão. 0 indivíduo aliena sua capacidade de trabalho e sua manifestação de energia ao capitalista individual, e não à classe dos capitalistas como tal. E, com isto, as categorias da liberdade e da igualdade ganham uma existência objetiva em meio às alternativas, às escolhas e ao arbítrio, desde de que estes pressuponham a capacidade dos indivíduos como algo alienável; ou seja, trata-se do modo pelo qual, em meio às relações jurídicas, são encaminhadas as determinações da produção capitalista na circulação.

\footnotetext{
${ }^{9}$ Colocamos o original em alemão aqui para que não se confunda o termo aqui utilizado, que é correlacionado ao sentido jurídico da venda, com os termos alienação (Entäusserung) e estranhamento (Entfremdung).
} 
A ação viva do trabalho, deste modo, aparece como propriedade privada, que não mais pertence ao trabalhador, mas ao capitalista. E, com isto, tem-se uma peculiar reificação: o trabalhador não é mais um anexo da terra como na servidão, ou da máquina como na escravidão; porém, com o trabalho assalariado, a própria capacidade dos indivíduos aparece como uma coisa. E, como tal, pode ser livremente alienada e apropriada. Para o que nos interessa mais diretamente, é bom destacar que a capacidade de trabalho aparece como uma propriedade a que, como sujeito, ele pode determinar.

E, com isto, têm-se alguns pontos importantes a serem explicitados: trazer à tona o debate sobre a pessoa, o sujeito e o Direito implica em compreender tanto a relação da circulação com a produção quanto ter em mente a peculiar reificação que se impõe na troca mercantil. 0 central aqui são as formas econômicas e seus desdobramentos, e não a relação jurídica. Se, por meio desta última, as relações econômicas são encaminhadas, o reconhecimento dos indivíduos como proprietários decorre da conformação objetiva da relação-capital; nesta última a produção se impõe, não porque o indivíduo esteja subsumido à terra ou á máquina, mas porque, como sujeito, tem papel ativo na alienação de sua própria capacidade e de suas manifestações de energia. Objetivamente, portanto, nas relações econômicas da sociedade capitalista, o trabalhador aparece como sujeito na medida mesma em que se submete, com liberdade formal, ao modo de apropriação capitalista da riqueza.

Uma questão central sobre o que aqui tratamos é: mesmo que haja uma determinação da esfera da circulação pela produção, e mesmo que os indivíduos se reconheçam como proprietários privados somente porque representam suas capacidades e manifestações como algo alienável, eles não podem ser reduzidos a esta sua função no sistema capitalista de produção. Há, por exemplo, diversos momentos da liberdade, da pessoa; tem-se uma dimensão colocada na subsunção a esta atividade econômica, que é refletida pelo Direito. Mas esta não é a única dimensão da individualidade moderna, que Marx trata nos Grundrisse. Porém, tem-se um fato: embora os indivíduos nunca possam ser reduzidos a proprietários, configuram-se, apresentam-se e se representam como tais. E, com isto, diz Marx que a 
circulação mercantil traz a correlação entre vontade livre, ausência de violência, necessidades mútuas, interesses mútuos, o interesse individual, o interesse universal social e o Direito:

Em decorrência, aqui entra de imediato o momento jurídico da pessoa e da liberdade, na medida em que está contida na primeira. Nenhum deles se apodera da propriedade do outro pela força. Cada um a cede voluntariamente. Mas isso não é tudo: o indivíduo A serve à necessidade do indivíduo B por meio da mercadoria a somente na medida em que, e porque, o indivíduo B serve à necessidade do indivíduo A por meio da mercadoria b, e vice-versa. Cada um serve ao outro para servir a si mesmo; cada um se serve reciprocamente do outro como seu meio. Ambos os aspectos estão agora presentes na consciência dos dois indivíduos: 1) que cada um só alcança seu objetivo à medida que serve como meio para o outro; 2) que cada um só devém meio para o outro (ser para outro) como fim em si mesmo (ser para si); 3) que a reciprocidade, segundo a qual cada um é ao mesmo tempo meio e fim, e de fato só alcança seu fim à medida que devém meio, e só devém meio à medida que se põe como fim em si mesmo; que, portanto, cada um se põe como ser para outro à medida que é ser para si, e que o outro se põe como ser para ele quando é ser para si mesmo - que essa reciprocidade é um fato necessário, pressuposto como condição natural da troca, mas que é, enquanto tal, indiferente para cada um dos dois trocadores, e essa reciprocidade tem interesse para o indivíduo apenas na medida em que satisfaz seu interesse, como interesse que exclui o interesse do outro, sem ligação com ele. 0 que significa dizer que o interesse comum, que aparece como motivo do ato como um todo, é certamente reconhecido como fato por ambas as partes, mas não é motivo enquanto tal, ao contrário, atua, por assim dizer, por detrás dos interesses particulares refletidos em si mesmos, do interesse singular contraposto ao do outro. Sob esse último aspecto, o indivíduo pode ter no máximo a consciência reconfortante de que a satisfação de seu interesse singular contraditório é justamente a realização da contradição superada, do interesse social universal. (MARX, 2011, p. 296-297)

Marx fala do momento jurídico da pessoa e da liberdade. E quanto a isto, é preciso trazer mais duas questões: primeiramente, há momentos que não são jurídicos da liberdade e da pessoa. Depois, este momento destas categorias - categorias estas que são multifacetadas e não podem ser reduzidas a uma dimensão da sociabilidade somente (como a jurídica) aparece de imediato somente. Ou seja, o momento jurídico da liberdade e da pessoa não corresponde àquele que pode ser compreendido remetendo às mediações que conformam a 
totalidade do concreto. Compreender tal aspecto é essencial para que o "método" de Marx possa ser apreendido corretamente. ${ }^{10} \mathrm{E}$, diz Marx:

O concreto é concreto porque é a síntese de múltiplas determinações, portanto, unidade da diversidade. Por essa razão, o concreto aparece no pensamento como processo da síntese, como resultado, não como ponto de partida, não obstante seja o ponto de partida efetivo e, em consequência, também o ponto de partida da intuição e da representação. (MARX, 2011, p. 78)

O processo de síntese pelo qual se compreende os momentos da pessoa e da liberdade parte do concreto; ele é o verdadeiro ponto de partida. Porém, ele remete para além do modo fenomênico de aparecimento da imediatez, no caso aqui analisado, ligado ao momento jurídico, e à dimensão jurídica que aparece na superfície das relações de produção capitalistas. Ou seja, logo de início, nota-se que, para Marx, a vontade livre que por meio do Direito permite a apropriação da mercadoria alheia não é o essencial na explicação do próprio movimento da economia capitalista. Por mais que isto possa aparecer na representação dos portadores práticos das relações econômicas como algo essencial, segundo Marx, trata-se de uma representação invertida da realidade. (Cf. SARTORI, 2019 b) Mas, mesmo que a representação dos indivíduos e dos agentes da produção a coisa se coloque invertida (Cf. GRESPAN, 2019), a vontade livre continua não sendo o aspecto principal, seja para explicar as formas econômicas, seja para compreender o Direito. (Cf. SARTORI, 2019 c)

Diz Marx que, de imediato, as necessidades dos indivíduos são mutuamente saciadas na troca mercantil; o fim dos indivíduos se realiza por meio de outros indivíduos. 0 reconhecimento deles como proprietários privados, objetivamente, implica na utilização do

10 Chasin faz uma importante ressalva quanto ao "método" marxiano, que não pode se confundir com a abordagem apriorística: "se por método se entende uma arrumação operativa, a priori, da subjetividade, consubstanciada por um conjunto normativo de procedimentos, ditos científicos, com os quais o investigador deve levar a cabo seu trabalho, então não há um método em Marx. Em adjacência, se todo o método pressupõe um fundamento gnosiológico, ou seja, uma teoria autônoma das faculdades humanas cognitivas, preliminarmente estabelecida, que sustente ao menos parcialmente a possibilidade do conhecimento, ou, então, se envolve e tem por compreendido um modus operandi universal da racionalidade, não há, igualmente, um problema do conhecimento na reflexão marxiana." (CHASIN, 2009, p. 89) 
outro como meio. E mais: segundo o autor dos Grundrisse, isto se dá na medida em que se conformam como fins em si mesmos.

Meios e fins, assim, aparecem como diferentes momentos do mesmo movimento, em que a reciprocidade dos proprietários é apreendida como condição natural da troca. E, assim, em meio a estas figuras da apresentação da realidade fenomênica, as pessoas são reconhecidas na medida em que há, ao mesmo tempo, a conformação de uma forma universal de sociabilidade e a oposição entre os indivíduos. Vê-se, portanto: aquilo que Marx traz ao falar da pessoa e do sujeito é esta conformação da individualidade e da universalidade, bem como o processo social objetivo que é engendrado pela esfera produtiva e que passa às constas do sujeito; este último, assim, é dominante ao dispor das próprias capacidades e energias como se fossem uma coisa. A livre vontade daqueles que operam pelas relações jurídicas ao encaminharem relações econômicas tem isso como pressuposto. Na esfera da competição e da circulação, o sujeito é aquele que se submete ao movimento da objetividade da sociedade capitalista, em que a relação entre pessoas e coisas é mediada pela mercadoria.

Tal aspecto, na medida em que Pachukanis traz uma análise cuidadosa do valor, e a relaciona à forma mercadoria e ao Direito, foi compreendida pelo autor da Teoria geral do Direito e marxismo. Porém, os pressupostos da esfera da circulação de mercadorias, bem como a relação destes pressupostos com formas econômicas que não se identificam de imediato com a forma mercadoria não são abordados com tanto cuidado pelo jurista soviético. Há aspectos essenciais que estão ligados à relação entre produção e circulação capitalistas. E, em meio a isto, tem-se um aspecto bastante dúplice, e que decorre da própria natureza do processo global de produção capitalista: a mútua dependência vem acompanhada da indiferença quanto ao interesse do outro. Tem-se, a ligação íntima entre o interesse social universal e o do indivíduo de um lado e, doutro, a oposição entre estes interesses, que se explicitam em meio às contradições da sociedade civil-burguesa.

Deste modo, a relação entre meios e fins recíprocos traz o reconhecimento da forma privada de apropriação como um dado natural. A reciprocidade aí desenvolvida tem por base o interesse dos proprietários privados; o interesse comum é reconhecido como um fato, mas é 
efetivo, não tanto em meio à reconciliação entre os indivíduos e o interesse social universal, mas ao passo que não são os sujeitos que determinam o conteúdo da relação econômica; eles encaminham a compra e venda, certamente. Mas o conteúdo desta transação passa por traz dos indivíduos e de seus interesses, como uma potência estranha. ${ }^{11} 0$ momento jurídico da pessoa e da liberdade, portanto, remete à reificação e à dependência diante das relações sociais de produção, mas também traz consigo o domínio de potências estranhas sobre os indivíduos. Elas são colocadas em movimento nas formas econômicas que estão pressupostas nas relações jurídicas. A compressão da pessoa e da liberdade, por conseguinte, passa pelo entendimento da sujeição dos indivíduos às metamorfoses das mercadorias, que só pode ser explicada em uma crítica da economia política; nela a anatomia da sociedade civil-burguesa traz consigo diversas relações e contradições entre formas econômicas; e somente em meio a tal processo que o papel do Direito pode ser analisado. A categoria sujeito, assim, precisa ser vista em um contexto mais amplo que aquele das categorias jurídicas. Mesmo que o momento jurídico da pessoa e da liberdade seja efetivo de imediato na circulação mercantil, há de se olhar para além da imediatez das relações sociais que se apresentam à representação dos portadores práticos das relações sociais.

\section{INDIVIDUALIDADE, SUJEITO, PESSOA E A UNIVERSALIDADE COLOCADA NA PRODUÇÃO CAPITALISTA}

Trata-se, portanto, de analisar, dentre outras coisas, a correlação entre a posição dos indivíduos como sujeitos, sua vontade livre, o interesse universal e os interesses meramente egoístas. Para que possamos fazer isto, há de se ver como que a produção capitalista, ao mesmo tempo, desenvolve a multilateralidade de um lado e, doutro, a autonomização. Sobre o assunto, diz Marx nos Grundrisse:

\footnotetext{
11 Em $O$ capital, ao ter isto em conta, diz Marx que a troca é, ao mesmo tempo, um processo individual e social: "cada possuidor de mercadorias só quer alienar sua mercadoria por outra mercadoria cujo valor de uso satisfaça sua necessidade. Nessa medida, a troca é para ele apenas um processo individual. Por outro lado, ele quer realizar sua mercadoria enquanto valor, em qualquer outra mercadoria que o agrade do mesmo valor, quer a sua própria mercadoria tenha ou não valor de uso para o possuidor da outra. Nessa medida, a troca é para ele um processo genericamente social. Mas o mesmo processo não pode ser simultaneamente para todos os possuidores de mercadorias apenas individual e, ao mesmo tempo, apenas genericamente social." (MARX, 1996 a, p.211)
} 
Pelo próprio ato da troca, o indivíduo, cada um dos indivíduos, está refletido em si mesmo como sujeito exclusivo e dominante (determinante) do ato da troca. Com isso, portanto, está posta a completa liberdade do indivíduo: transação voluntária; nenhuma violência de parte a parte; posição de si como meio, ou a serviço, unicamente como meio de se pôr como fim em si, como o dominante e o prevalecente; enfim, o interesse egoísta, que não realiza nenhum interesse superior; o outro também é reconhecido e conhecido como sujeito que realiza seu interesse egoísta exatamente da mesma maneira, de modo que ambos sabem que o interesse comum consiste precisamente na troca do interesse egoísta em sua bilateralidade, multilateralidade e autonomização. 0 interesse universal é justamente a universalidade dos interesses egoístas. (MARX, 2011, p. 297)

No ato de troca, os indivíduos colocam-se como sujeitos exclusivos e dominantes na medida em que se submetem às coisas, no caso, às mercadorias. A completa liberdade do indivíduo, assim, aparece como aquela em que ele domina de modo exclusivo as coisas como proprietário sendo, ao mesmo tempo, dominado pelo movimento das mercadorias. Ou seja, deve-se apontar algo essencial ao nosso tema: a categoria sujeito, aqui, explicita a inversão que se coloca na imediatez da sociedade; ela, a partir da categoria pessoa, pode até mesmo possuir um momento jurídico. Mas ambas as categorias não "são" propriamente jurídicas; são categorias econômicas que, somente de imediato, aparecem em um momento jurídico, sendo reconhecidas pelo Estado. Este momento da liberdade e da pessoa é importante para o encaminhamento das relações econômicas, mas não as explica.

O essencial está na correlação entre produção, distribuição, circulação, troca e consumo, bem como no movimento das próprias formas econômicas. ${ }^{12} 0$ momento jurídico certamente joga um papel importante no reconhecimento destas categorias; mas elas não são, em si, jurídicas.

Ao analisar a circulação mercantil, percebe-se que a tematização do sujeito e da pessoa remete a aspectos mais amplos da forma mercadoria que aquele presente na dimensão jurídica. E, deste modo, o Direito é de grande relevo para que se compreenda a totalidade do

\footnotetext{
${ }^{12}$ Sobre o assunto, vale conferir as análises de Dussel. (2012)
} 
movimento da reprodução do capital. Porém, o papel ativo que joga a esfera jurídica pressupõe aquilo que precisa ser explicado, e que, ao se ter em mente o sujeito e pessoa, envolve a individualidade moderna e sua conformação objetiva, cuja base última está no movimento das categorias econômicas. E, assim, o indivíduo está refletido em si mesmo como dominante e exclusivo devido à conformação objetiva das formas econômicas, e não primordialmente devido a um momento jurídico, mesmo que este também precise ser compreendido. Dizer que o momento jurídico determina o encaminhamento das relações econômicas seria inverter causa e efeito, sujeito e predicado. E o tratamento destas inversões, que são efetivas na sociedade capitalista ao mesmo tempo em que são irracionais, é constante em Marx, que é bastante crítico a este procedimento especulativo. ${ }^{13}$ No entanto, como já mencionamos, de acordo com o autor de $O$ capital, de imediato, é justamente isto que parece ser verdadeiro. Como diz Marx no livro III, no processo de troca e "na concorrência aparece, pois, tudo invertido." (MARX, 1986, p. 160)14 No sistema capitalista de produção, os indivíduos, portanto, conformam-se em meio à universalidade de determinadas relações de produção, mas esta universalidade se impõe a eles como uma potência estranhada. ${ }^{15}$ A monstruosa coleção de mercadorias em que se representa a riqueza da sociedade capitalista traz esta imediatez.

Este é o pano de fundo sobre o qual se colocam as relações jurídicas. E, pelo que estamos trazendo aqui, pode-se dizer que neste pano de fundo é que, de imediato, as categorias pessoa e o sujeito são efetivos. Na inversão mencionada, e em uma forma peculiar de reificação, assenta-se a universalidade do domínio do capital. 0 sujeito é dominante e tem exclusividade, primeiramente, por meio alienação de sua capacidade de trabalho. Assim, as

\footnotetext{
13 Sobre o assunto, Cf. SARTORI, 2019 a, b, 2020.

14 Logo em seguida, continua o autor: "a figura acabada das relações econômicas, tal como se mostra na superfície, em sua existência real e portanto também nas concepções mediante as quais os portadores e os agentes dessas relações procuram se esclarecer sobre as mesmas, difere consideravelmente, sendo de fato o inverso, o oposto, de sua figura medular interna, essencial mas oculta, e do conceito que lhe corresponde." (MARX,1986, p. 160)

15 Aqui não podemos tratar do assunto polêmico relacionado às categorias alienação (Entäusserung), estranhamento (Entfremdung), bem como de suas relações com a potência entranhada, mencionada. Para algumas colocações sobre tal questão, Cf. NEGRI, 2016. Sobre o contexto mais geral destas categorias na obra de Marx, Cf. LUKÁCS, 2013.
} 
categorias econômicas relacionadas a isto precisam ser consideradas ao se analisar o papel que o Direito cumpre nos Grundrisse e em $O$ capital.

Nota-se, portanto, que as passagens que trazemos acima passam justamente pelo típico tema pachukaniano, a correlação entre forma mercadoria e o Direito. Notamos, porém, que a caracterização marxiana da questão é bastante mais ampla e remete à reificação que se conforma na relação entre pessoas e coisas. Passa-se também pelo processo pelo qual, na realidade mesma, há uma inversão entre sujeito e objeto. Não se pode deixar de lado tais aspectos ao tratar de nossa questão. ${ }^{16}$

Segundo Marx, o essencial é tratar do processo social que torna isto possível e que se reproduz repondo esta base, assentada na conformação da relação-capital. E, assim, não há como trazer à tona nosso tema ao traçar uma relação direta entre a forma mercadoria e o Direito. ${ }^{17}$ Em verdade, há de se compreender o momento jurídico das categorias ao se considerar a relação entre os pressupostos das formas econômicas, que são essenciais ao modo de produção capitalista, como mercadoria, dinheiro e capital. A rigor, a reificação das relações sociais também precisa ser compreendida por meio desta tematização. A equação entre forma mercantil e forma jurídica, portanto, precisa de mais mediações.

Tais reificação e inversão aparecem na imediatez da sociedade capitalista, refletindo-se no momento jurídico da liberdade e da pessoa. Porém, na medida mesma em que se tem uma transação voluntária e que não advém imediatamente de nenhuma violência, há a imposição das categorias econômicas da produção vigente na sociedade capitalista. Para Marx, o movimento das mercadorias, que supõe o dinheiro e o capital, traz os indivíduos proprietários como predicados do processo econômico que se impõe como uma potência estranha. Mas eles aparecem como sujeitos, e são sujeitos proprietários. Eles são dominantes na medida em que se submetem a um movimento que lhes é estranho. No imediato, portanto, uma leitura atenda dos Grundrisse explicita como que se tem uma inversão entre sujeito e predicado

\footnotetext{
${ }^{16}$ Sobre o contexto mais geral do assunto, Cf. ALVES, 2013.

17 Isto se dá mesmo que Pachukanis diga que "crítica de Marx do sujeito de direito, que deriva imediatamente da análise da forma mercadoria." (PACHUKANIS, 2017, p. 61)
} 
(poderíamos, ao usar a dicção do livro III, tratar disto como a inversão entre sujeito e objeto $^{18}$ ); e, assim, pode-se dizer, também sob este ângulo: a noção de sujeito trazida nesta obra de Marx de modo algum pode ser reduzida ao seu momento jurídico, colocado na categoria pessoa, correlacionada por Pachukanis e pelos pachukanianos brasileiros ao sujeito de direito. E mais: sobre esta última categoria, há de se notar que a pessoa, trazida por Marx nas passagens acima, pode ter um momento jurídico (tal qual a liberdade), mas não ela se reduz a este.

A categoria pessoa não corresponde àquela do sujeito de direito. Se ela pode ser estudada tendo por base a obra de Marx, tal qual ocorre em Pachukanis, tal equação não está em Marx. Ela é um desenvolvimento original do autor de Teoria geral do Direito e o marxismo. (Cf. SARTORI, 2015)

De modo algum, portanto, a análise marxiana presente no texto que aqui analisamos não pode corroborar com a interpretação pachukaniana, em que a categoria sujeito de direito não só já está presente em Marx, correspondendo à categoria pessoa, como é central ao autor alemão e à sua crítica ao Direito. 0 sujeito, aqui, aparece por meio do reconhecimento do interesse privado, que, de acordo com nosso autor, é um fruto de uma peculiar reificação, da imposição do processo produtivo e da oposição entre interesses egoístas e o interesse universal. Trata-se da liberdade da pessoa subsumida ao movimento das mercadorias, que supõe a imposição da relação-capital como um processo que passa às costas do sujeito na medida mesma em que este último aparece como exclusivo e dominante.

No que é preciso que se destaque outro ponto, também relacionado, nos Grundrisse, à universalidade e à individualidade que se apresentam na esfera de circulação de mercadorias.

\footnotetext{
18 Diz Marx ao tratar do mais-valor e do lucro, bem como de sua forma de aparição na imediatez das relações sociais: "pelo fato de que todas as partes do capital aparecem igualmente como fontes de valor excedente lucro, a relação-capital é mistificada. A maneira pela qual, mediante a transição pela taxa de lucro, a mais-valia é transformada na forma de lucro é, no entanto, apenas o desenvolvimento ulterior da inversão que já ocorria durante o processo de produção, de sujeito e objeto." (MARX, 1986, p. 35-36)
} 
Em meio ao movimento das formas econômicas, os indivíduos realizam transações voluntárias e livres de coerção violenta; aparecem como um fim em si, como dominantes, como sujeitos exclusivos e dominantes. Trata-se de um cenário que parece ter saído de uma teorização sobre a razão prática, como aquela de Kant. Esta é também uma dimensão da pessoa, da liberdade e do sujeito.

Tal qual se dá com o Direito, pode-se desenvolver uma teorização sobre a moral a partir daí. Mas, do mesmo modo, há de se dizer que este não é o enfoque de Marx. Pachukanis chega a levantar tal ponto, identificando a moral kantiana como a moral burguesa por excelência. Traz isto na medida em que encontra na tematização de Kant a universalidade e a reciprocidade da troca mercantil. Nota-se, porém, que há mais questões em jogo aqui, de modo que certamente é preciso reconhecer os méritos do autor da Teoria geral do Direito e o marxismo; e isto se dá na medida em que talvez os Grundrisse explicite alguns temas de modo mais claro que $O$ capital, de que parte o jurista soviético.

Há de se admitir, porém, que, tal qual no caso do sujeito de direito, trata-se mais de um desenvolvimento própria a Pachukanis que de uma teorização de Marx. (Cf. SARTORI, 2015)

Voltemos ao texto do próprio Marx, pois.

Um dos polos do ato de troca, portanto, é tal sujeito. Outro é a efetividade deste sujeito no interesse egoísta. E, assim, trata-se certamente de uma esfera em que se realiza o interesse universal. Porém, a universalidade conformada pela sociedade capitalista é essencialmente antagônica; e, deste modo, trata-se da universalidade do interesse egoísta. A reciprocidade, assim, é a expressão da bilateralidade do interesse egoísta, e da mútua correlação entre meios e fins. E este movimento entre autonomização e interesse universal pode até mesmo se refletir no Direito e na moral, mas, nos Grundrisse, o tratamento da questão se dá ao se analisar o movimento das categorias econômicas.

Tem-se, assim, uma espécie de superação da autonomização dos indivíduos proprietários na reciprocidade e na bilateralidade, colocadas em uma espécie de interesse 
comum. Nele, como disse Marx acima, "o indivíduo pode ter no máximo a consciência reconfortante de que a satisfação de seu interesse singular contraditório é justamente a realização da contradição superada, do interesse social universal.” (MARX, 2011, p. 297) 0 interesse comum, portanto, não é simplesmente incompatível com os atos de troca; ele se efetiva contraditoriamente, por meio de uma forma de universalidade que traz consigo a contradição entre "os indivíduos universalmente desenvolvidos" (MARX, 2011, p. 164) e a sujeição destes ao processo econômico. Assim, a tematização marxiana sobre a pessoa, o sujeito e o Direito remetem à formação da individualidade moderna em meio a estas contradições.

A conexão é um produto dos indivíduos. É um produto histórico. Faz parte de uma determinada fase de seu desenvolvimento. A condição estranhada [Fremdartigkeit] e a autonomia com que ainda existe frente aos indivíduos demonstram somente que estes estão ainda no processo de criação das condições de sua vida social, em lugar de terem começado a vida social a partir dessas condições. É a conexão natural e espontânea de indivíduos em meio a relações de produção determinadas, estreitas. Os indivíduos universalmente desenvolvidos, cujas relações sociais, como relações próprias e comunitárias, estão igualmente submetidas ao seu próprio controle comunitário, não são um produto da natureza, mas da história. 0 grau e a universalidade do desenvolvimento das capacidades em que essa individualidade se torna possível pressupõem justamente a produção sobre a base dos valores de troca, que, com a universalidade do estranhamento do indivíduo de si e dos outros, primeiro produz a universalidade e multilateralidade de suas relações e habilidades. (MARX, 2011, p.164)

Nos Grundrisse, a noção de sujeito e de pessoa está relacionada ao contexto mais geral, aquele da oposição entre individualidade e desenvolvimento das forças produtivas, estas últimas que produzem uma forma de universalidade que se impõe como uma potência estranha. E, deste modo, a famosa contradição entre forças produtivas e relações de produção dá base também a este âmbito.

Na obra, a tematização marxiana do sujeito está colocada explicitamente em conjunto com aquela do Direito; porém, ficam ainda mais claras que em 0 capital (SARTORI, 2019 a) as 
ligações do sujeito que trata Marx com os assuntos que apontamos acima, e que extrapolam em muito a esfera e as relações jurídicas. Ou seja, também aqui, a categoria pessoa não traz uma correspondência total com o jurídico sujeito de direito. Antes, o movimento das formas econômicas tratadas por Marx faz com que percebamos: tanto no que diz respeito à liberdade quanto à pessoa, tem-se um momento jurídico; mas este tem muito menos destaque na obra de Marx do que parecem supor Pachukanis e a tradição pachukaniana que é hegemônica no Brasil. 0 autor da Teoria geral do Direito e o marxismo acerta ao relacionar a teoria do valor com a compreensão das relações jurídicas na sociedade capitalista. Porém, talvez tenha apreendido isto de modo menos mediado que aquele de Marx.

E, neste ponto, há de se ter mente que a categoria sujeito de direito não é central a Marx e não corresponde à noção de sujeito ou de pessoa, que aparecem nos Grundrisse em meio à compreensão da individualidade moderna. Esta última, em verdade, desenvolve suas potências devido ao incremento das forças produtivas; porém a maneira pela qual este incremento se dá - com a imposição da produção capitalista de mercadorias, com a reificação, com as potências estranhadas aviltando a personalidade dos indivíduos etc. - traz o domínio das coisas sobre os homens.

E, desta maneira, outro tema importante para 0 capital (Cf. SARTORI, 2019 a) - aquele do fetichismo e da reificação - está presente ao se tratar das categorias da pessoa e do sujeito. 0 processo histórico de desenvolvimento da individualidade moderna resulta nestas contradições. E, assim, sobre esta base, a superação da ligação imediada com a natureza, na sociedade capitalista, é efetiva como o estranhamento das potências sociais, que se contrapõem aos indivíduos.

O processo produtivo que se coloca por meio da reificação das relações sociais traz também a conexão real e efetiva entre os indivíduos; a atomização, bem como a formação de um sujeito exclusivo e dominante, de um proprietário, é a outra face do processo de socialização; isto significa que os indivíduos criam as suas próprias relações sociais, que aparecem como uma potência estranha a eles. Supera-se, assim, uma condição natural e espontânea no sentido estrito e, para que se use a dicção hegeliana - por vezes mencionada 
por Marx - aparece uma espécie de segunda natureza, já essencialmente social. Vê-se, portanto: contraditoriamente, o modo pelo qual os indivíduos podem se colocar como universalmente desenvolvidos passa pela subsunção da individualidade à reprodução do capital. São sujeitos proprietários, são dominantes e exclusivos; mas são reconhecidos somente como proprietários. 0 papel que isto exerce no incremento das forças produtivas é grande. E, assim, também na circulação de mercadorias, está colocado em potência o indivíduo universalmente desenvolvido. A vontade livre, mediada pelas mercadorias, volta-se contra tais sujeitos em meio a relações sociais que, neste ponto do incremento das forças produtivas, já podem ser superadas.

As suas relações próprias e comunitárias aparecem por meio de formas econômicas como a mercadoria, o dinheiro e o capital. Ou seja, o grau de desenvolvimento desta individualidade pressupõe a produção com base nos valores de troca. Tal universalidade, assim, é aquela do estranhamento do indivíduo de si e dos outros; mas, ao mesmo tempo, a multilateralidade de suas relações e habilidades já é uma realidade. 0 sistema capitalista de produção, portanto, desenvolve indivíduos universais, multilaterais, mas os mantém presos às suas posições na cadeia produtiva. ${ }^{19}$

Porém, o progresso - mesmo que baseado no aviltamento dos indivíduos - é real: “em estágios anteriores de desenvolvimento, o indivíduo singular aparece mais completo precisamente porque não elaborou ainda a plenitude de suas relações e não as pôs diante de si como poderes e relações sociais independentes dele." (MARX, 2011, p. 164) A forma de universalidade da produção capitalista engendra relações sociais que superam a ligação imediata do homem com a natureza; e, em seu lugar, traz relações próprias e comunitárias que, em sua figura capitalista, são essencialmente estranhadas.

A realização dos indivíduos universalmente desenvolvidos, portanto, caso possa se reconciliar com o interesse universal, está em uma forma de sociabilidade em que as capacidades e a energia dos homens não são mais apropriadas privadamente visando ao enriquecimento do mundo das mercadorias. Trata-se da necessidade de uma forma não

\footnotetext{
${ }^{19}$ Sobre o assunto, no contexto mais amplo da obra de Marx e da tematização sobre o progresso, Cf. SARTORI, 2018.
} 
antagônica de relação dos indivíduos multilaterais com o interesse universal, ou seja, tem-se a necessidade de superação do capitalismo.

E, pelo que vemos nesta obra de Marx, a compreensão das categorias pessoa e sujeito precisa se dar nestes meandros. Mesmo que as categorias jurídicas precisem ser explicadas ao se compreender este processe que citamos, em Marx, não são elas que são analisadas com o maior cuidado e ênfase. Novamente, isto não invalida a teoria pachukaniana; mas faz com que se possa questionar a fidelidade deste autor ao texto marxiano. (Cf. SARTORI, 2015, 2020) Chega-se, assim, a uma análise que faz com que percebamos grandes acertos de Pachukanis, principalmente ao compreender o Direito em meio à valorização do valor; porém, mesmo ao se analisar a relação entre a esfera jurídica e a forma mercadoria - ou seja, ao se fazer o mesmo que o autor soviético fez - percebemos que o espectro da crítica marxiana é mais amplo, e precisa ser visto com mais cuidado do que normalmente se supõe. E, com isto, parte da compreensão da própria realidade acaba por ser deixada de lado por Pachukanis.

\section{TROCA, ALIENAÇÃo, RELAÇÃo ECONÔMICA E RELAÇÃo JURÍDICA}

Se, acima, analisamos, sobretudo a relação entre Direito e forma mercadoria na esfera da circulação, agora, continuaremos esta análise ao mesmo tempo em que remeteremos à relação existente entre a esfera jurídica e a forma dinheiro. Analisaremos também o modo pelo qual há uma correlação entre o tratamento marxiano do Direito e a esfera da distribuição. Vejamos, pois.

No sistema capitalista de produção, como já mencionado, “o interesse universal é justamente a universalidade dos interesses egoístas" (MARX, 2011, p. 297) de tal modo que esta situação - em que os indivíduos se reconhecem como pessoas ao se conformarem como proprietários privados de suas capacidades, que, por sua vez, são passíveis de alienação como uma coisa - precisaria ser superada. Tal superação se daria por meio das potencialidades desenvolvidas no próprio modo de produção capitalista. Se olharmos por este ângulo também, de modo algum a concepção marxiana de pessoa pode ser reduzida à categoria jurídica de sujeito de direito. 0 essencial à análise marxiana não é o momento jurídico, mas o 
engendramento de possibilidades dos indivíduos universalmente desenvolvidos em meio ao próprio estranhamento das relações sociais. Trata-se também de uma crítica ao modo pelo qual estas relações se contrapõem a suas próprias individualidades, que aparecem como aquelas de pessoas na medida em que são dominadas pelas coisas. A questão, como já aludido, tem por fundamental a compreensão do valor e de seu papel na produção e reprodução do capitalista de produção. E isto necessita de uma crítica à economia política. (Cf. SARTORI, 2020)

Pachukanis traz para a sua análise a teoria do valor e, assim, é bom ver como que, nos Grundrisse, Marx trata desta temática ao passar pelo assunto que abordamos neste pequeno escrito:

O ser-para-si autônomo do valor perante a capacidade de trabalho - daí sua existência como capital -, a indiferença objetiva autossuficiente, a estranheza das condições objetivas do trabalho perante a capacidade de trabalho viva, que chega ao ponto em que essas condições confrontam a pessoa do trabalhador na pessoa do capitalista como personificações com vontade e interesse próprios -, essa dissociação, separação absoluta entre a propriedade, i.e., as condições materiais do trabalho, e a capacidade de trabalho viva, condições materiais que se confrontam com ela como propriedade alheia, como a realidade de outra pessoa jurídica, como território absoluto da vontade dessa pessoa - e que, por outro lado, o trabalho aparece consequentemente como trabalho alheio perante o valor personificado no capitalista ou perante as condições objetivas de trabalho -, essa separação absoluta entre propriedade e trabalho, entre a capacidade de trabalho viva e as condições de sua realização, entre trabalho objetivado e vivo, entre o valor e a atividade criadora de valor - daí também a estranheza do conteúdo do trabalho para o próprio trabalhador -, esse divórcio agora aparece igualmente como produto do próprio trabalho, como concretização, como objetivação de seus próprios momentos. Pois, pelo próprio novo ato de produção que só confirma a troca entre capital e trabalho vivo que lhe antecede -, o trabalho excedente e, em consequência, o valor excedente, o produto excedente, enfim, o resultado total do trabalho (tanto do trabalho excedente como do necessário) foram postos como capital, como valor de troca confrontando de maneira autônoma e indiferente a capacidade de trabalho viva, ou confrontando-a como seu mero valor de uso. A capacidade de trabalho se apropriou unicamente das condições subjetivas do 
trabalho necessário - os meios de subsistência para a capacidade de trabalho produtora, i.e., sua reprodução como mera capacidade de trabalho separada das condições de sua efetivação - e pôs essas próprias condições como coisas, valores, que a confrontam em uma personificação estranha e dominante. A capacidade de trabalho não sai mais rica do processo, sai mais pobre do que nele entrou. (MARX, 2011, p. 600-601)

0 que se explicita é a oposição entre o valor e o trabalho. ${ }^{20}$ Por mais que a capacidade de trabalho produza o valor, este se volta contra ela, como um ser-para-si autônomo. 0 capital é justamente a exteriorização da capacidade de trabalho que se torna alheia e estranha aos trabalhadores.

A capacidade de trabalho viva, assim, tem uma existência autonomizada nas formas do valor e do capital. Ela defronta-se como algo estranho tanto à pessoa do capitalista como do trabalhador; e, assim, estes aparecem como personificações de relações sociais estranhadas; e, novamente, destacamos que o contexto em que se insere a categoria pessoa nos Grundrisse - e em $O$ capital (Cf. SARTORI, 2019 a) - é muito mais amplo que aquele da categoria jurídica sujeito de direito.

Há, porém, uma dimensão jurídica nas pessoas; tanto é assim que Marx destaca a propriedade dos meios de produção como algo que pode se afastar das próprias condições materiais de produção: por meio da propriedade de pessoas jurídicas, a propriedade jurídica pode estar dissociada da posse imediata dos meios de produção. E, neste ponto, é preciso trazer duas ressalvas importantes: a primeira delas diz respeito à categoria pessoa jurídica. 0 uso marxiano da categoria é muito distinto daquele da teoria do Direito; Marx aqui está falando da pessoa do capitalista e do trabalhador e, ao destacar a dimensão jurídica da categoria pessoa, refere-se à propriedade alheia que, nesta relação, aparece como a realidade de outra pessoa jurídica. Ou seja, no texto marxiano, a dimensão jurídica da pessoa é tratada

\footnotetext{
${ }^{20}$ Um desenvolvimento polêmico e original da questão aparece em NEGRI, 2016.
} 
com referência ao termo pessoa jurídica, que não significa a existência autônoma da empresa, de um conjunto de bens, mas algo que se coloca nas próprias pessoas físicas. ${ }^{21}$

A dicção marxiana, portanto, não dialoga com os debates da teoria do Direito. Ao trazer a compreensão da pessoa e do sujeito, seu embate é com a economia política, que trata do movimento das categorias e das formas econômicas da sociedade civil-burguesa. Ou seja, dizer que a categoria pessoa corresponde ao sujeito de direito da teoria do Direito é fazer uma leitura muito enviesada da obra marxiana. (Cf. SARTORI, 2019 a) 0 essencial aqui é o modo pelo qual a propriedade das condições materiais de produção separa-se do processo imediato de produção. E, assim, a produção de mercadorias se dá pelo trabalho social de uma classe ao passo que a apropriação do valor se dá por outra classe, que detém a propriedade jurídica dos meios de produção. Trata-se da estranheza das condições de trabalho, da dissociação e da separação absoluta entre trabalho e condições de produção.

Na medida em que a capacidade de trabalho se volta à produção de valor, o ato de produção pressupõe a troca entre capital e trabalho vivo. A estranheza do conteúdo do trabalho decorre da atividade do trabalhador, mas tal conteúdo é posto como capital e como valor; e, assim, a efetivação do trabalho significa que a capacidade de trabalho não sai mais rica do processo: as condições de efetivação da capacidade de trabalho são postas como coisas, valores. 0 processo capitalista de trabalho é aquele no qual as pessoas se deparam umas com as outras e as coisas dominam as pessoas.

Novamente, a relação entre pessoas e coisas é central para Marx; e a superação desta oposição na imediatidade ocorre no fato de as pessoas se tornarem personificações de relações sociais estranhadas. Trata-se, nas palavras de Marx, de uma personificação entranhada e dominante, tal qual antes vimos o autor mencionar ao trata do sujeito exclusivo e dominante. Ou seja, os homens produzem mercadorias e valores, os quais, na medida em que os indivíduos figuram como personificações dominantes, sujeitam-nos a algo autônomo e

\footnotetext{
21 Aqui trazemos a oposição típica da doutrina jurídica entre pessoa física, ou natural, de um lado, e pessoa jurídica doutro. Como pretendemos estar deixando claro, este uso, relacionado à categoria sujeito de direito, é muito diferente do marxiano.
} 
independente, que daria o télos da totalidade do processo produtivo. A razão do processo capitalista de produção não está no bem-estar do trabalhador, mas na reprodução do valor que se assenta nas mercadorias primariamente.

A alienação da capacidade de trabalho, portanto, passa pela pessoa cuja vontade é livre na medida em que se submete à desefetivação; o sujeito dominante e exclusivo, neste processo, é dominado pelos objetos por ele produzido, de modo que, novamente, tem-se a inversão entre sujeito e predicado, entre sujeito e objeto. Isto, tal qual anteriormente apontado, é central à passagem.

Porém, não há como não deixar de apontar que a pessoa jurídica tem um papel bastante importante neste texto. Ele não é somente aquele que destaca Pachukanis - realizar a mediação jurídica na compra e venda da força de trabalho -; embora tal dimensão esteja presente, a ênfase de Marx na pessoa jurídica está no divórcio entre as condições de produção e a propriedade. A função do Direito está muito mais ligada às condições de apropriação da riqueza que à produção do valor.

A esfera jurídica, deste modo, está bastante relacionada com a distribuição do maisvalor. 0 papel do Direito é importante na reprodução do modo de produção capitalista. Porém, relaciona-se não só à circulação e à produção de mercadorias, em que, respectivamente, gerase e se realiza o mais-valor; antes, uma função do Direito que tem grande relevo na análise marxiana diz respeito à apropriação do valor já produzido anteriormente e disponível na esfera da distribuição.

A relação entre Direito e o encaminhamento da distribuição de riqueza, que é determinada pela produção, é trazida no livro III de $O$ capital, que não é central à análise pachukaniana, focada no livro I. (Cf. SARTORI, 2020) Nos Grundrisse, por sua vez, primeiramente, ao se ter em mente a criação do valor pela capacidade de trabalho dos indivíduos, o autor alemão analisa como que a dimensão jurídica da pessoa e da liberdade são importantes, mas, ao ficarem na superfície das relações sociais, precisam ser vistas em relação com as outras dimensões destas categorias, que emergem do movimento das categorias 
econômicas. Depois, Marx passa a trazer à tona a função do Direito na distribuição do maisvalor, por meio de relações jurídicas, como a herança, por exemplo. ${ }^{22}$ Mas há de se admitir que o essencial, nos Grundrisse e em $O$ capital, não é o Direito.

Aqui, portanto, as suas críticas se voltam aos economistas que trazem a produção como algo supratemporal ${ }^{23}$, ao passo que, "na distribuição, em troca, a humanidade deve ter se permitido de fato toda espécie de arbítrio." (MARX, 2011, p. 59) E, assim, Marx realiza uma crítica àqueles que se atém à imediatidade de modo acrítico. Os juristas certamente o fazem. Porém, o principal alvo de Marx aqui está nos economistas burgueses. Um dos grandes temas dos Grundrisse - e de $O$ capital (Cf. SARTORI, 2019 a) - está na compreensão da relação entre as esferas da produção, da distribuição, da circulação, da troca e do consumo. É neste terreno que a alienação da capacidade de trabalho está na obra de Marx, por mais que não se possa deixar de lado outras facetas das categorias analisadas. Para compreender o Direto na obra do autor sempre é preciso ter isto em conta.

Ao tratar da dimensão jurídica da pessoa, Marx faz referência ao território absoluto da vontade dessa pessoa, de modo que demonstra que, em meio ao Direito, aceita-se aquilo que aparece de imediato na produção capitalista como um dogma. A esfera jurídica, assim, reflete de modo acrítico a imediatez da efetividade da sociedade capitalista. Isto, porém, não significa que na pessoa jurídica se tenha simplesmente uma espécie de falsa consciência: mesmo que a apropriação do valor seja determinada pelo modo de produção, na superfície da sociedade capitalista, efetivamente apropria-se da riqueza a partir da separação entre propriedade e condições materiais de produção. A dimensão jurídica da pessoa realmente traz um campo em que a vontade é livre, aquele da propriedade; o proprietário dispõe livremente das coisas sob seu domínio. Ocorre, porém, que esta livre disposição traz consigo o fato, determinado

\footnotetext{
22 Analisaremos tal questão mais à frente no texto.

23 Diz Marx sobre o assunto: "para os economistas [...] a produção deve ser representada - veja, por exemplo, Mill -, à diferença da distribuição etc., como enquadrada em leis naturais eternas, independentes da história, oportunidade em que as relações burguesas são furtivamente contrabandeadas como irrevogáveis leis naturais da sociedade in abstracto" (MARX, 2011, p. 59)
} 
pela produção social, de as coisas se colocarem como mercadorias, cujo movimento aparece como autônomo e subordinado às determinações da relação-capital.

Sobre tal ponto, Marx diz que o resultado do trabalho - tanto aquele excedente, que o autor chamará posteriormente de mais-trabalho, e que dá origem ao que chamou em $O$ capital de mais-valor, quanto o necessário à reprodução da capacidade de trabalho - é posto como capital.

E, assim, o produto do trabalho coloca-se em uma relação de contraposição diante do trabalhador. A objetivação dos momentos do trabalho se coloca como oposto e estranho a este, como capital. E, assim, a inversão entre sujeito e objeto, que é mediada pelas diversas dimensões da pessoa, aparece em ato na produção capitalista de mercadorias e de valor, cuja imediatez é tomada como dada pelo Direito. A inversão mencionada decorre das próprias relações econômicas capitalistas; ela só é reconhecida oficialmente pelo Direito. A pessoa jurídica, bem como a dimensão jurídica da liberdade e da pessoa, pressupõem tal processo econômico, ao mesmo tempo em que não são simplesmente ilusórias; têm efetividade, mas ficam associadas à conformação dos indivíduos como portadores de relações de produção estranhadas. Sobre tal tema, em um momento posterior do texto, diz Marx:

A troca de equivalentes, que parece subentender a propriedade sobre o produto do próprio trabalho - e, por conseguinte, pôr como idênticos: a apropriação pelo trabalho, o processo econômico efetivo da apropriação [Zueigen-Machen], e propriedade sobre o trabalho objetivado; o que há pouco parecia processo real, aqui é reconhecido como relação jurídica, i.e., como condição universal da produção, e, por isso, é reconhecido legalmente, posto como expressão da vontade universal -, muda repentinamente, revela-se, por uma dialética necessária, divórcio absoluto entre trabalho e propriedade e apropriação de trabalho alheio sem troca, sem equivalente. A produção baseada no valor de troca, sobre cuja superfície acontece aquela troca livre e igual de equivalentes, é no fundo troca de trabalho objetivado como valor de troca pelo trabalho vivo como valor de uso, ou, como também pode ser expresso, comportamento do trabalho em relação às suas condições objetivas - e, por essa razão, com a objetividade criada pelo próprio trabalho - como propriedade alheia: alienação [Entäußerung] do trabalho. Por outro lado, é condição do valor de troca ser 
medido pelo tempo de trabalho, e, por isso, o trabalho vivo - não o seu valor - como medida dos valores. É uma ilusão acreditar que, em todas as condições de produção, a produção e, em consequência, a sociedade se baseiam na troca de simples trabalho por trabalho. Nas diversas formas em que o trabalho se relaciona com suas condições de produção como sua propriedade, a reprodução do trabalhador não é posta de modo algum por mero trabalho, pois sua relação de propriedade não é o resultado, mas o pressuposto de seu trabalho." (MARX, 2011, p. 685-686)

A troca equivalente, que se coloca na esfera da circulação, foi o ponto de partida da análise pachukaniana. $\mathrm{O}$ autor soviético, desta maneira, enfatiza uma das esferas da economia em que o Direito aparece de modo mais pungente. Ao fazê-lo, porém, vem a destacar a ligação da relação jurídica com a figura do processo econômico que é capaz de produzir o mais-valor, a compra e venda da força de trabalho. (Cf. PAHUKANIS, 2017) Para Marx, porém, a coisa se dá também doutro modo.

Mesmo que esta dimensão para a qual Pachukanis dá ênfase seja importante, o Direito aparece com muita força no autor dos Grundrisse ao tratar da apropriação do mais-valor, que já foi produzido. A reificação das relações sociais que decorre de a capacidade de trabalho estar posta como uma coisa apropriável como uma mercadoria qualquer é que é reconhecida na relação jurídica. Este é o ponto de partida desta, e não algo que é produzido por meio dela. 0 fato de isso aparecer como uma condição universal de produção, ser reconhecido legalmente e posto como vontade universal, remete ao processo que torna as relações materiais de produção uma espécie de segunda natureza.

A reciprocidade, a troca de equivalentes, assim, pressupõe a apropriação do trabalho alheio, sem equivalentes. ${ }^{24}$ Trata-se da apropriação do que Marx chama nos Grundrisse de trabalho excedente, e que viria se ser chamado posteriormente de mais-trabalho. No momento em que o processo real passa a ser reconhecido como relação jurídica, isto apaga-se e a produção capitalista vem a ser pressuposta. Na superfície, tem-se a troca equivalente, em que se move a pessoa, dotada de livre vontade e de capacidade jurídica; a alienação do

\footnotetext{
${ }^{24}$ Este ponto será melhor desenvolvido por Marx em $O$ capital, ao tratar da mercadoria força de trabalho, e de sua capacidade de produzir valor. Cf. RUBIN, 1987.
} 
trabalho, bem como o valor de troca, por outro lado, são os reais sujeitos do processo - dirá Marx posteriormente em $O$ capital que o valor "passa continuamente de uma forma para outra, sem perder-se nesse movimento, e assim se transforma num sujeito automático." (MARX, 1996 a, p. 273) E, deste modo, há uma determinação das relações de produção sobre as formas pelas quais se dá a apropriação da riqueza social; o processo de produção, assim, não é simplesmente algo decorrente do trabalho em seu sentido mais amplo, mas deste trabalho colocado em meio a relações determinadas de produção, que antecedem a propriedade jurídica.

As condições materiais de produção aparecem como propriedade na medida em que a atividade do trabalhador não é aquela que diretamente coloca as formas de propriedade; antes, tem-se o oposto: o pressuposto do trabalho são diferentes formas de apropriação da riqueza, que, por sua vez, são determinadas pelas distintas figuras e formas da produção. E, assim, tem-se, na superfície, as relações jurídicas reconhecendo o conteúdo das relações econômicas; sob este solo, opera a dimensão jurídica da liberdade e da pessoa, que tem base o valor, a exploração da capacidade de trabalho, bem como aquilo de essencial à conformação da circulação capitalista de mercadorias.

Ou seja, as relações jurídicas certamente refletem um conteúdo que pressupõe a forma mercantil. Isto foi corretamente destacado por Pachukanis. Porém, talvez o autor soviético tenha dado muita ênfase ao papel do Direito neste processo; em Marx, há uma mediação essencial para que o processo de circulação possa ser compreendido, aquele do dinheiro. Passa-se, assim, à necessidade do entendimento da forma dinheiro, para que se possa tratar do processo que Marx procura explicitar.

E, se é verdade que o fetichismo do dinheiro remete necessariamente ao fetichismo da mercadoria, não há uma simples identidade entre estas duas formas econômicas. A alienação da capacidade de trabalho, a troca equivalente, a reificação das relações sociais etc. decorrem, em última análise, da produção capitalista de mercadorias, mas precisam ser entendidas ao se ter em conta a correlação entre as formas mercadoria, dinheiro e capital. A compreensão das categorias sujeito e pessoa precisa passar por estes meandros também. Sem isto, toma-se um 
atalho indevido das formas econômicas às formas jurídicas (Cf. SARTORI,2020); e, se é verdade o que dissemos, não é possível estabelecer uma relação direta entre a forma mercadoria e aquilo que Pachukanis chama de forma jurídica. (Cf. SARTORI, 2020) 0 percurso para que se possa entender a relação entre as formas jurídicas e as formas econômicas é mais cheio de meandros do que se supõe normalmente.

Na passagem marxiana na qual se apoia grande parte da teoria pachukaniana, Marx fala da "relação jurídica, cuja forma é o contrato" (MARX, 1996 a, p. 79); e, neste sentido, pode-se falar de uma menção do autor de $O$ capital a uma forma jurídica. ${ }^{25}$ Ao olharmos por este lado, Pachukanis tem grande parcela de razão em sua ênfase. (Cf. SARTORI, 2015) Porém é essencial que se perceba que as relações jurídicas, embora se relacionem com a alienação da capacidade de trabalho dos indivíduos, encaminham também diversas outras transações, cujo conteúdo é ainda mais estranhado diante das pessoas, ocorrendo, em grande parte, com a mediação da forma dinheiro. ${ }^{26}$

E, assim, para que se possa tratar das categorias sujeito e pessoa no pensamento de Marx, é preciso ter isto em conta. Veja-se como que a igualdade e o nivelamento, que permeiam uma dimensão jurídica da igualdade, aparecem explicitamente na forma dinheiro:

Mas como o dinheiro aparece aqui como material, como mercadoria universal dos contratos, toda diferença entre os contratantes é, ao contrário, apagada. Se o dinheiro devém objeto da acumulação, o sujeito parece só retirar dinheiro da circulação, i.e., a forma universal da riqueza, desde que não retire dela mercadorias do mesmo preço. Logo, se um dos indivíduos acumula e o outro não, nenhum deles o faz às custas do outro. Um deles usufrui a riqueza real, o outro se apossa da forma universal da riqueza. Se um deles empobrece e o outro enriquece, esse é seu livre-arbítrio e não tem origem na própria relação econômica, no próprio vínculo econômico em que estão postos um em relação ao outro. A própria herança e outras relações jurídicas

\footnotetext{
${ }^{25}$ Embora isto fique mais claro no modo expresso pelo qual Marx menciona a questão ao contra Wagner: "mostrei na análise da circulação de mercadorias que no escambo desenvolvido as partes se reconhecem tacitamente como pessoas iguais e como proprietários dos respectivos bens a serem por eles trocados; eles já o fazem ao oferecer uns para os outros seus bens e ao entrar em acordo uns com os outros sobre o negócio. Essa relação fática que se origina primeiro na e através da própria troca adquire mais tarde forma jurídica no contrato etc.; mas essa forma não cria nem o seu conteúdo, a troca, nem a relação nela existente das pessoas entre si, mas vice-versa." (MARX, 2017, p. 273)

${ }^{26}$ Tal aspecto também aparece em $O$ capital, como bem destacou Vinícius Casalino. (2019)
} 
similares que perpetuam as desigualdades assim surgidas em nada afetam essa liberdade e essa igualdade naturais. Se a relação original do indivíduo A não está em contradição com esse sistema, essa contradição certamente não poderá se produzir porque o indivíduo B assume o lugar do indivíduo A, perpetuando-o. Trata-se, ao contrário, de uma vigência da determinação social para além do limite natural da vida: uma consolidação dessa determinação em face da ação contingente da natureza, cujo efeito enquanto tal seria muito mais a supressão da liberdade do indivíduo. Ademais, como o indivíduo nessa relação nada mais é do que a individuação do dinheiro, ele é enquanto tal tão imortal quanto o dinheiro, sendo sua representação por herdeiros, ao contrário, a efetivação dessa determinação. (MARX, 2011, p. 300-301)

A igualdade entre os contratantes coloca-se também, e de modo mais pungente ainda, a partir da forma dinheiro. 0 sujeito que aparece nessa esfera é aquele que lida com a forma universal da mercadoria, a saber, o próprio dinheiro. Aqui, novamente, tem-se a apropriação da riqueza por meio de formas que não se coloca imediatamente no processo imediato de produção; por meio da mercadoria universal, é possível deter uma forma universal de riqueza. A igualdade entre os indivíduos, assim, aparece por meio do modo pelo qual as pessoas se reconhecem como proprietárias. Porém, há algo mais: aqui, sequer a relação entre pessoas e coisas parece ser central para que se possa apropriar da riqueza social; antes, a riqueza aparece no fetiche do dinheiro ao passo que este parece ter uma existência autônoma e se põe como material: na medida mesma em que se afasta do processo produtivo é que o dinheiro se apresenta como material e como mercadoria universal dos contratos.

Ou seja, o tratamento marxiano do Direito, por vezes, parece prescindir das pessoas concretas. Na forma dinheiro, a mediação mútua entre pessoas e coisas aparece apagada e a riqueza aparece em uma figura universalizada e, ao mesmo tempo, autonomizada diante do processo produtivo.

E, assim, nota-se que o conteúdo das relações jurídicas que perpassam os contratos é dado pelas relações econômicas. Isto, porém, ocorre de modo ainda mais destacado por meio do dinheiro. Na troca entre indivíduos proprietários, a igualdade aparece, assim, nas formas econômicas: um deles se apropria da riqueza real outro da forma universal da riqueza. E, 
assim, a igualdade que Marx traz aqui à tona não é somente aquela entre indivíduos colocados jurídica e politicamente em patamar de igualdade; tem-se a reciprocidade na medida em que a diferença entre os contratantes é apagada não tanto devido à correlação entre a forma mercadoria e a forma jurídica, como em Pachukanis, mas devido à relação entre a forma mercadora e a forma dinheiro. Ou seja, para que os contratos possam operar, é necessário um grau de autonomização das formas econômicas que ainda não está presente ao se ter em conta a análise da mercadoria. Para que seja possível enxergar as conexões reais que permeiam a efetividade da sociedade capitalista, não basta analisar o fetichismo da mercadoria: é preciso passar pelo fetichismo do dinheiro, em suas diversas figuras. ${ }^{27}$ As relações jurídicas também se colocam sobre a impessoalidade e a imoralidade daquele que aparece como equivalente e como mercadoria universal, o dinheiro. Voltar os olhos à circulação certamente implica em reconhecer que a capacidade de trabalho aparece como uma mercadoria; também perpassa a compreensão dos indivíduos enquanto pessoas que se apropriam de coisas em meio a relações sociais reificadas. Porém, tal esfera do processo global de produção precisa ser vista ao se ter em conta o dinheiro.

A reciprocidade dos contratos, de imediato, dá-se justamente entre proprietários de mercadorias e de dinheiro. Ou seja, a caracterização dos proprietários traz uma diferença na própria identidade deles enquanto pessoas: de um lado, apropria-se da riqueza real, doutro, da forma universal de riqueza. E o Direito está colocado diante da forma mercadoria e da forma dinheiro.

Nos Grundrisse, portanto, as formas econômicas e suas mútuas relações precisam ser compreendidas antes que se estabeleça uma visão sobre o Direito na obra. Neste caso, a correlação entre a forma mercadoria e a forma dinheiro traz um terreno em que se coloca o livre-arbítrio de modo ainda mais bem desenvolvido por Marx. Se antes o autor mencionava a livre vontade de modo a questionar a dimensão jurídica da pessoa e da liberdade, aqui ele trata do conteúdo das relações jurídicas com mais cuidado: há, de fato, empobrecimento e enriquecimento quando o dinheiro devém objeto de acumulação e isto se deve ao próprio

\footnotetext{
${ }^{27}$ Sobre esta questão, é essencial a análise do livro III de $O$ capital. Cf. SARTORI, 2019 b, c.
} 
movimento das formas econômicas. A distribuição da riqueza parece ser arbitrária, mas devém da produção. Isto tudo, porém, dá-se ao passo que parece advir do livre-arbítrio e de relações jurídicas. Por meio do contrato e da vontade, os indivíduos operam como proprietários de mercadorias e de dinheiro, tendo-se, de um lado, a riqueza real, doutro a riqueza e sua forma universal. Com isto, efetivamente, os dois indivíduos aumentam sua riqueza, um a real outro aquela em forma universal. Tratar-se-ia de um campo em que a igualdade e a liberdade apareceriam como características das próprias pessoas, e como algo natural. A igualdade, portanto, não decorre só de uma caracterização jurídica e ilusória das relações de produção capitalistas; ela devém do desenvolvimento das próprias formas econômicas que caracterizam este modo de produção.

A alienação das mercadorias, portanto, opera pela forma jurídica contratual, mas o faz reconhecendo estas relações econômicas, que dão o conteúdo da relação jurídica. A igualdade e a liberdade que aparecem na esfera jurídica são as desenvolvidas a partir do domínio do valor, que opera por meio das metamorfoses das formas mercadoria, dinheiro e capital. As categorias pessoa e sujeito, em Marx, precisam ser compreendidas tendo todo este processo em mente. ${ }^{28}$ Caso se procure trazer uma conotação essencialmente jurídica para estes termos, reduz-se demais o entendimento marxiano. Nota-se ainda que a análise marxiana do Direito precisa de um destaque especial também em outras esferas que aquela da circulação, como a distribuição, em que o mais-valor é apropriado.

\section{RELAÇÕES JURÍDICAS, HERANÇA E SUJEITO}

Uma questão essencial, porém, aparece na citação acima ao passo que a liberdade e igualdade naturais mencionadas acima não são simplesmente suprimidas pelas desigualdades

\footnotetext{
${ }^{28}$ A análise de Pachukanis, por outro lado, traz que "se a análise da forma-mercadoria revela o sentido histórico concreto da categoria do sujeito e expõe as bases abstratas do esquema da ideologia jurídica, então o processo histórico de desenvolvimento da economia mercantil-monetária e mercantil-capitalista acompanha a realização desses esquemas na forma da superestrutura jurídica concreta. Na medida em que as relações entre as pessoas se constroem como relação de sujeitos, temos todas as condições para o desenvolvimento da superestrutura jurídica com suas leis formais, seus tribunais, seus processos, seus advogados, e assim por diante." (PACHUKANIS, 2017, p. 62)
} 
colocadas na distribuição da riqueza a partir de relações jurídicas específicas, como aquelas colocadas na herança.

E, assim, é preciso que se aponte: neste aspecto, a ênfase marxiana nas relações jurídicas se dá, não tanto, na correlação entre a produção e a circulação, por meio da compra e venda (a alienação) da capacidade de trabalho, como ocorre em Pachukanis. A dimensão jurídica aparece na medida em que Marx a vê como aquela que não explica o que ele está analisando; porém, ao se focar na esfera da distribuição do mais-valor já produzido, a questão se apresenta de modo ligeiramente distinto: a partir de certo afastamento do processo imediato de produção, e depois de o valor já ter sido produzido e realizado, as relações jurídicas perpetuam desigualdades que já estão colocadas nas relações econômicas de modo muito mais destacado. Ou seja, se olharmos para a distribuição, veremos o papel ativo do Direito de modo proeminente, talvez até mais que na circulação. Na análise desta última, Marx enfatiza a esfera jurídica de modo negativo, ao criticar a ideologia que emerge desta dimensão na imediatidade da efetividade da troca mercantil. Já ao tratar da esfera da distribuição, a autonomização do Direito é marcante. Com isto, Marx menciona a herança e outras relações jurídicas semelhantes como aquelas que decorrem do livre-arbítrio na medida em que parecem estar separadas da relação econômica mesma. Tal aspecto é essencial para compreender o Direito nos Grundrisse.

Com isto, a partir da vontade, tanto a herança como outras relações jurídicas têm um papel ativo ao perpetuar as desigualdades surgidas das relações econômicas; e aqui chega-se a um ponto em que a propriedade jurídica - apartada da atividade diante das condições materiais de produção - tem um grau grande de fetichização. Não só o proprietário não precisa trabalhar diretamente com os meios de produção (quem o faz são trabalhadores), mas também pode ser substituído no direito a apropriar-se da riqueza socialmente produzida. Assim, tem-se uma separação entre a propriedade e as condições materiais de trabalho; porém, também emergem o direito sucessório - e outros direitos advindos de relações jurídicas - perpetuando as desigualdades advindas das relações econômicas, trazendo um destaque especial ao Direito e às relações jurídicas em meio às formas econômicas. 
Trata-se, segundo Marx, da vigência da determinação social para além do limite natural da vida. Caso a coisa não se desse deste modo, a mencionada liberdade e igualdade naturais, do ponto de vista do sistema capitalista de produção, seriam suprimidas. A supressão da liberdade do indivíduo, nestas condições, significaria que sua condição de personificação de relações sociais que o tornam uma pessoa proprietária não sobreviveria à sua própria vida. E, assim, uma função importante do Direito está em perpetuar tal liberdade. Com a dimensão jurídica da liberdade, não se tem só a livre vontade que se atém à imediatidade da sociedade capitalista; há também a perpetuação das relações sociais de produção para além das individualidades concretas que são suas portadoras. E isto é essencial para a reprodução do capital. A herança, por exemplo, em verdade, suprime mencionada liberdade natural; instaura uma situação que rompe com qualquer robinsonada relativa à liberdade. Trata-se de indivíduos concretos, de famílias de patrimônio $\mathrm{x}, \mathrm{y}$ ou z. Mas a coisa se passa de modo distinto na concepção jurídica: o indivíduo e sujeito desta relação social se configura como a individuação do dinheiro e, assim, tendo o dinheiro continuidade, as relações jurídicas podem garantir que as personificações destas relações sociais estranhadas possam continuar a ter vigência mesmo depois da morte do indivíduo concreto. Assim, a liberdade natural do indivíduo é suprimida com sua morte, mas continua tendo vigência com a herança. Os indivíduos, nesta relação jurídica aparecem como individuações do dinheiro. Os sujeitos, aqui, relacionam-se tanto com a forma mercadoria como com a forma dinheiro, tudo isso, claro, pressupondo-se o movimento do capital.

E, neste ponto, há algo bastante relevante para o nosso tema: tratar da pessoa e do sujeito, ao levar em consideração do Direito, leva a considerar que há uma importância considerável não só da relação entre a forma mercadoria e as formas jurídicas; tem-se uma ênfase toda especial na forma dinheiro, bem como na autonomização desta e das relações jurídicas diante do processo produtivo.

Se o Direito e a dimensão jurídica da pessoa e da liberdade estivessem relacionados diretamente com a forma mercadoria, a grande função do Direito estaria, como quer Pachukanis, na circulação mercantil. Ocorre, porém, que nesta esfera da economia, o central 
na compreensão da circulação não é o momento jurídico, mas a correlação entre as formas mercadoria, dinheiro e capital.

Há de se apontar também que, em Marx, na circulação tem-se muito mais uma crítica à redutora dimensão jurídica que a mostra de como ela é efetiva. Ela certamente encaminha relações econômicas, mas não determina o conteúdo delas; mesmo a igualdade e o nivelamento destas esferas trazem consigo um papel proeminente do dinheiro e não tanto do sujeito de direito. Já na esfera da distribuição - depois que o mais-valor já foi produzido e, em grande parte, realizado -, a efetivação da determinação do Direito aparece em formas econômicas muito mais autonomizadas, como as diversas figuras do capital monetário. (Cf. SARTORI, 2019 b, c) E, segundo Marx, isto significa que o livre-arbítrio exerce seu papel com maior grau de afastamento das determinações trazidas pela produção e, por isto também, o Direito parece ser autônomo diante das relações sociais que a ele dão base. Este ponto, porém, seria analisado com muito mais cuidado no livro III de 0 capital. $^{29}$

O Direito, aqui, é essencial ao possibilitar a apropriação da riqueza sem que se tenha a posse imediata dos meios de produção. Há, assim, uma separação, que Marx diz ser absoluta, entre o exercício imediato do trabalho e a apropriação da riqueza produzida pelos trabalhadores. Trata-se da ligação entre a esfera da distribuição e a de produção. Isto, como destacou bem Pachukanis, passa pela exploração da força de trabalho (nos Grundrisse chamada de capacidade de trabalho); porém, não é só: como iria mostrar Marx no livro III de O capital, diversas parcelas da burguesia (comercial, financeira, por exemplo), apropriam-se da riqueza de modo muito mais mediado do que a burguesia industrial. E a autonomização, tanto das formas econômicas, quanto do Direito, é essencial para que isso possa se dar na sociedade capitalista pela esfera da distribuição. (Cf. SARTORI, 2020)

\footnotetext{
${ }^{29}$ Ali, as transações, expectativas, ficções e garantias jurídicas são analisadas ao se ter em conta, sobretudo, o capital portador de juros. Tal aspecto, bem como a análise de diversas formas jurídicas, não é analisado por Pachukanis. Porém, aqui, não podemos tratar do assunto. Cf. SARTORI, 2019 b, c, 2020.
} 
Nos Grundrisse, tal separação da posse das condições materiais de produção diante da propriedade jurídica delas é essencial para Marx, inclusive, por assim dizer, metodologicamente.

A oposição entre a relação jurídica e a econômica é trazida à tona pelo autor alemão ao passo que já Hegel tomaria a inversão que aparece na imediatidade da sociedade capitalista como aquela racional e efetiva. Ao tratar do sujeito, das relações jurídicas, da posse e da propriedade, diz Marx:

O todo como um todo de pensamentos, tal como aparece na cabeça, é um produto da cabeça pensante que se apropria do mundo do único modo que lhe é possível, um modo que é diferente de sua apropriação artística, religiosa e prático-mental. 0 sujeito real, como antes, continua a existir em sua autonomia fora da cabeça; isso, claro, enquanto a cabeça se comportar apenas de forma especulativa, apenas teoricamente. Por isso, também no método teórico o sujeito, a sociedade, tem de estar continuamente presente como pressuposto da representação. Mas essas categorias simples não têm igualmente uma existência independente, histórica ou natural, antes das categorias mais concretas? Isto depende. Hegel, por exemplo, começa corretamente a filosofia do direito com a posse como a mais simples relação jurídica do sujeito. Mas não existe posse antes da família ou das relações de dominação e de servidão, que são relações muito mais concretas. Pelo contrário, seria correto dizer que existem famílias, tribos, que somente possuem, mas não têm propriedade. Com relação à propriedade, portanto, a categoria mais simples aparece como relação de associações mais simples de famílias ou tribos. Na sociedade mais avançada, a propriedade aparece como a relação mais simples de uma organização desenvolvida. Mas o substrato mais concreto, do qual a posse é relação, é sempre pressuposto. É possível imaginar um selvagem singular possuidor. Nesse caso, porém, a posse não é uma relação jurídica. Não é correto que a posse desenvolve-se historicamente na família. A posse pressupõe sempre, ao contrário, esta "categoria jurídica mais concreta". (MARX, 2011, p. 79)

Marx aponta na sociedade o sujeito real. A questão, assim, é compreender como que as diferentes sociedades funcionam; no caso, as sociedades têm diversas dimensões, dentre elas, a jurídica. Em Hegel, o ponto de partida para a análise das formas de apropriação não foram 
as condições materiais de produção, de que decorre a posse em suas diversas figuras históricas, mas a relação jurídica do sujeito. (Cf. LUKÁCS, 2018) Ou seja, ao passo que seria necessário partir de um espectro maior da posse, enxergando como ela depende inicialmente de formas sociais como famílias, tribos etc., no autor da Fenomenologia do espírito o ponto de partida é a relação jurídica do sujeito - para que utilizemos a dicção de Marx noutros momentos, da pessoa jurídica.

0 erro de Hegel, portanto, consiste em trazer de modo teleológico a existência da moderna propriedade da sociedade civil-burguesa como o critério para a posse; e esta última, por sua vez, passa a ser vista, não tanto como uma relação social dependente da apropriação da natureza, das formas de trabalho e da organização social, mas da relação jurídica de propriedade. Hegel, portanto, toma a inversão presente na imediatidade da sociedade capitalista como racional e efetiva, ao passo que ela não pode ser explanada por si mesma. 0 autor, assim, aceita a inversão colocada na própria realidade.

Na própria posição marxiana sobre Hegel há uma crítica àqueles que tomam como ponto de partida as relações jurídicas e o sujeito de direito. Mesmo em uma teorização marxista sobre a esfera jurídica, tal contraposição ao autor da Filosofia do Direito continua válida, possuindo uma validade, por assim, dizer, metodológica. Contrapor-se à especulação hegeliana e ao método da economia política significa, dentre outras coisas, questionar a naturalização da propriedade privada e das relações que dela decorrem. Ao se ter em mente o ponto de partida da teorização, isto é igualmente verdadeiro. Em Marx, a crítica ao Direito está subordinada à crítica à economia política. ${ }^{30}$

\footnotetext{
${ }^{30}$ Para uma análise do modo, por vezes vacilante, pelo qual isto ocorre em Pachukanis, Cf. SARTORI, 2015. O autor traz uma ligação muito direta do trabalho abstrato com o sujeito de direito também, e o faz ao trazer certas temáticas da teoria do Direito ao primeiro plano: "todo homem torna-se um homem em geral, todo trabalho torna-se um trabalho social útil em geral, todo indivíduo torna-se um sujeito de direito abstrato. Ao mesmo tempo, também a norma toma a forma lógica acabada da lei abstrata geral.” (PACHUKANIS, 2017, p. 127) Veja-se que ele se coloca explicitamente no "terreno do inimigo": segundo o autor, "[uma] crítica à jurisprudência burguesa, do ponto de vista do socialismo científico, deve tomar como modelo a crítica à economia política burguesa, como o fez Marx. Para isso, ela deve, antes de tudo, adentrar no território do inimigo, ou seja, não deve deixar de lado as generalizações e as abstrações que foram trabalhadas pelos juristas burgueses e que se originam de uma necessidade de sua própria época e de sua própria classe, mas, ao expor a análise dessas categorias abstratas, revelar seu verdadeiro significado, em outras palavras, demonstrar
} 
A relação entre a posse e a propriedade deve ser vista em meio a isto. E, assim, se na sociedade civil-burguesa, a posse e a propriedade são determinações que só podem ser compreendidas em sua relação de reflexão, isto não quer dizer que a posse não possa existir sem a propriedade. E, neste caso específico, a posse é uma relação social, mas não uma relação jurídica. A posse também não se desenvolve, como quer Hegel, na família - no caso, na relação entre homem e mulher como sujeitos jurídicos ${ }^{31}$ - mas nas condições materiais de produção, que propiciam formas distintas de apropriação da natureza. Ao questionar a posição hegeliana, vê-se que inversão entre as relações jurídicas e as econômicas está presente também no autor alemão, que é bastante criticado por Marx neste ponto.

A relação de oposição entre posse e propriedade pressupõe a categoria jurídica mais concreta, aquela da propriedade privada burguesa. E, para que voltemos à questão da herança e das relações jurídicas que se colocam em meio à distribuição da riqueza, há de se dizer: as categorias jurídicas mais concretas estão assentadas nas formas econômicas da sociedade capitalista, como a mercadoria, o dinheiro e o capital, não podendo ser compreendidas fora do movimento destas mesmas categorias.

Os momentos do fenômeno jurídico precisam ser vistos com cuidado em uma crítica marxista ao Direito; Marx, porém, é bastante claro no sentido de estes momentos precisarem ser enxergados em meio às categorias econômicas e ao desenvolvimento contraditório destas na sociedade capitalista.

Se no livro III de $O$ capital, nosso autor analisa, dentre outras coisas, as transações jurídicas em meio a figuras distintas do capital, como o capital portador de juros (Cf. SARTORI, 2019 b, c), sendo a correlação entre forma capital e Direito o essencial; já nos Grundrisse, um momento central, além daquele corretamente destacado por Pachukanis, vem a ser a correlação entre a forma dinheiro e as relações jurídicas. E, se é verdade, como bem

as condições históricas da forma jurídica.” (PACHUKANIS, 2017, p. 80) Como vimos, o procedimento marxiano é diferente.

${ }^{31} \mathrm{O}$ tema da opressão da mulher é essencial e percorre o pensamento de Marx e de Engels. Porém, aqui, não podemos tratar da questão, que implicaria na análise de muitas outras obras como, por exemplo, $O$ manifesto, O capital, Os manuscritos etnológicos, Ideologia alemã, Origem da família, da propriedade privada e do Estado, entre outros. 
destacou o autor da Teoria geral do Direito e o marxismo, que há uma relação entre forma jurídica e mercantil, na obra que aqui analisamos - e, acreditamos, em $O$ capital também (Cf. SARTORI, 2020) - isto se dá de modo mais mediado do que ele assinala. A dimensão jurídica da pessoa e da liberdade são criticadas por Marx ao tratar da troca mercantil; porém, a análise desta última tem como pressuposto determinações só compreensíveis no desenvolvimento da forma dinheiro, e que completam a análise marxiana da mercadoria.

Metodologicamente, por assim dizer, Marx contrapõe-se a considerar central a relação jurídica do sujeito; e esta crítica foi muito bem apreendida por Pachukanis. Porém, o autor soviético não pode destacar com o cuidado devido o papel do Direito em meio à autonomização das formas econômicas do dinheiro e do capital. ${ }^{32}$ Por isto, até certo ponto com razão, o autor da Teoria geral do Direito e o marxismo aproxima o Direito da esfera de circulação mercantil. Porém, ele deixa de destacar o papel da esfera jurídica na distribuição, como Marx faz, até certo ponto, já nos Grundrisse, mas principalmente no livro II e III de $O$ capital. Mesmo no que toca uma questão essencial para a anatomia da sociedade civilburguesa - aquela da apropriação desigual da riqueza - a análise de Marx sobre o Direito e as formas econômicas é mais complexa do que normalmente parece acreditar-se, também, na esteira de Teoria geral do Direito e marxismo. Para entender a hipostasia da vontade livre, é preciso que a autonomização do Direito seja analisada, também, em meio às formas econômicas estranhadas, que se relacionam com a forma mercadoria, mas não podem ser reduzidas a ela.

E mais: tais formas desenvolvem-se a partir da correlação e antagonismo entre os momentos do processo global de produção. E, se é verdade que há uma determinação da distribuição pela produção, igualmente verdadeiro é que as relações jurídicas encaminham relações econômicas - como a herança - que são essenciais na perpetuação das desigualdades das formações sociais capitalistas. A partir de uma relação sui generis com a forma dinheiro, os sujeitos aparecem não só como pessoas cujo reconhecimento se dá em sua propriedade; a partir da sua formação como individuações do dinheiro, as relações sociais são

\footnotetext{
${ }^{32}$ Para uma análise do livro I de $O$ capital sobre este ponto, Cf. CASALINO, 2019.
} 
operacionalizadas de tal modo que as personificações das relações sociais estranhadas não precisam ter uma identidade fixa em um indivíduo concreto. E esta questão é essencial para a análise da economia capitalista, em que as empresas não se identificam com os seus proprietários nominais. (Cf. SARTORI, 2019 b, c) Neste sentido, reiteramos novamente: de modo algum é possível reduzir o tratamento marxiano do sujeito, da pessoa e do Direito à categoria jurídica sujeito de direito. Mesmo uma análise aprofundada do processo de circulação do capital não prescinde do entendimento da reprodução da sociedade capitalista, em que a forma dinheiro e a forma capital, em suas diversas figuras, são essenciais.

\section{APONTAMENTOS FINAIS: IGUALDADE DOS SUJEITOS, PESSOA, PRIVILÉGIO E DIREITO}

A inversão entre sujeito e objeto não é simplesmente um fenômeno filosófico. Ela se dá real e efetivamente na sociedade; as categorias pessoa e sujeito, em Marx, são vistas em meio a este processo. E, por isto, a análise marxiana do Direito não toma as categorias jurídicas como parâmetro. Mesmo o uso da categoria pessoa jurídica é muito diferente no autor de $O$ capital que na doutrina e na teoria do Direito. Ao trazer à tona a categoria, Marx trata da dimensão jurídica da pessoa e da liberdade mostrando como que ater-se a estas seria extremamente equivocado. Assim, ele mostra como que o conteúdo econômico da troca - que é explicitado na autovalorização do valor a partir da esfera da produção - é que coloca a liberdade ao passo que a forma econômica é que traz a igualdade. Assim, as relações jurídicas são, em parte ideológicas e, em parte, a base econômica colocada em outra potência conjuntamente com as relações políticas e sociais. E, neste sentido, seria preciso voltar os olhos ao processo econômico real pelo qual as formas jurídicas passam do privilégio ao Direito.

Se, portanto, a forma econômica, a troca, põe a igualdade dos sujeitos em todos os sentidos, o conteúdo, a matéria, tanto individual como objetiva, que impele à troca, põe a liberdade. Igualdade e liberdade, por conseguinte, não apenas são respeitadas na troca baseada em valores de troca, mas a troca de valores de troca é a base produtiva, real, de toda igualdade e liberdade. Como ideias puras, são simples expressões idealizadas dessa base; quando desenvolvidas em relações jurídicas, políticas e sociais, são apenas essa base em uma outra potência. E isso também se verifica historicamente. A igualdade e a liberdade nessa extensão são exatamente o 
oposto da liberdade e igualdade antigas, que não têm justamente o valor de troca desenvolvido como fundamento, mas se extinguem com seu desenvolvimento. Elas pressupõem relações de produção que ainda não haviam se realizado no mundo antigo nem tampouco na Idade Média. 0 trabalho compulsório direto é o fundamento do mundo antigo; a comunidade repousa sobre ele como suporte real; na Idade Média, prevalece como fundamento o próprio trabalho como privilégio, ainda em sua particularização, não como trabalho produzindo universalmente valor de troca. 0 trabalho não é nem compulsório nem, como no segundo caso, tem lugar em respeito a uma entidade comunal como algo superior (corporações). (MARX, 2011, p. 297-298)

A igualdade dos sujeitos, ao mesmo tempo em que é vista como natural, é posta pela forma econômica da troca. E isto se daria em todos os sentidos. A igualdade presente nas diversas dimensões do sujeito e da pessoa, assim, não seriam algo advindo imediatamente dos indivíduos que efetivamente atuam e produzem, mas algo que decorre da subordinação destes indivíduos à forma da troca, que pressupõe a produção capitalista. Esta última coloca-se sobre os próprios pés somente quanto a circulação de mercadorias, por meio da forma dinheiro, visa à acumulação e, portanto, pressupõe a relação-capital. 0 conteúdo efetivo da liberdade do sujeito está nesta relação. Para que se use da dicção de $O$ capital, trata-se do sujeito automático do capital. (Cf. SARTORI, 2019 a)

Ao trazer o desenvolvimento deste conteúdo, Marx se volta, não tanto às formas jurídicas, mas ao desencadeamento das formas econômicas, que se dá historicamente. Há, assim, uma contraposição entre as relações jurídicas da sociedade capitalista e aquelas do mundo antigo e da Idade Média. 0 solo sobre o qual se colocaria a antiguidade seria o trabalho compulsório; a Idade Média, por seu turno, remete ao privilégio, e não ao Direito universal, tendo-se os atributos do trabalho - positiva ou negativamente - ligados ao nascimento. As individualidades que se desenvolvem nestes contextos históricos são, ou ligadas a alguma entidade comunal como as corporações de ofício, ou aparecem como contraparte da figura do trabalho compulsório dos escravos.

A individualidade unida como a comunidade antiga pressupõe a escravidão. Já na sociedade capitalista, tem-se os direitos do homem e seu caráter universal se opondo aos 
privilégios. E, com isto, tais direitos são o reconhecimento de formas econômicas e sociais que solaparam o privilégio de nascimento, bem como a diferenciação medieval em estamentos. Doutro lado, desenvolve-se uma noção de pessoa que se coloca para além dos cidadãos da pólis. No que se deve apontar: tanto de um lado - a supressão o privilégio -, quanto noutro em uma concepção mais ampla da igualdade entre os indivíduos -, as dimensões do sujeito e da pessoa são muitas, embora o Direito tenha exercido um papel importante na passagem do modo de produção feudal ao capitalista. A igualdade e a liberdade desta sociedade emergente são o exato oposto da liberdade e da igualdade antigas. E isto se dá, não tanto devido à igualdade jurídica e política, mas essencialmente porque o sistema social daí decorrente tem no valor de troca seu fundamento. Esta é a base da igualdade dos sujeitos entre si; e o conteúdo das relações jurídicas está igualmente pressuposto nas relações materiais de produção emergentes.

O interessante da análise marxiana, porém, não está só neste modo de ver a liberdade e a igualdade da moderna sociedade civil-burguesa; antes, o autor traz à tona o modo pelo qual o Direito, até certo ponto, consegue se autonomizar diante de seu conteúdo concreto. As formas jurídicas têm uma autonomia relativa, ao mesmo tempo em que esta autonomização mesma decorre de sua relação com as formas econômicas como a mercadoria, o dinheiro e o capital. No caso do Direito, ele opera não só em meio à circulação mercantil e de modo imediato na compra e venda da capacidade de trabalho dos indivíduos. Por mais que isto também ocorra, tal alienação pressupõe não só a forma mercadoria, mas o dinheiro e o movimento subjacente do capital. Ou seja, os indivíduos aparecem não só como guardiões de mercadorias e possuidores de mercadorias, como uma leitura apressada do livro I de $O$ capital pode fazer parecer. Ao analisar a questão, há de se destacar que "as mercadorias não podem por si mesmas ir ao mercado e se trocar. Devemos, portanto, voltar a vista para seus guardiões, os possuidores de mercadorias." (MARX, 1996 a, 79) Porém, é também preciso dizer que os indivíduos não são só portadores da relação social de troca de mercadorias, mas individuações do dinheiro, cujo movimento é determinado pela acumulação do capital. E as relações jurídicas que advém desta dimensão da pessoa e da liberdade são analisadas por 
Marx, não só ao trazer uma análise da circulação de mercadorias, mas ao tratar da reprodução do capital e da distribuição do mais-valor.

Com isto em mente, é possível que se compreenda, a partir da análise das próprias formas econômicas como que faz parte do ser-propriamente-assim do Direito certo grau de autonomização. Somente ao se passar pela análise da conformação da individualidade em diversos momentos da história é possível entender o tratamento marxiano do sujeito e da pessoa; em meio a este tratamento, pode-se compreender uma questão central ao autor, aquela do desenvolvimento desigual de diversas formas sociais, que, em verdade, têm sua existência anterior àquela do capitalismo. Dinheiro, Direito, mercadoria, por exemplo, são formas sociais pré-capitalistas. Porém, adquirem um sentido específico na medida em que a sua base se torna o valor, o que se dá no sistema capitalista de produção. Somente ao se ter em conta tais questões é possível tentar desvendar uma questão essencial colocada por Marx:

A relação desigual do desenvolvimento da produção material com, por exemplo, o desenvolvimento artístico. Não conceber de modo algum o conceito de progresso na abstração habitual. Com a arte moderna etc., essa desproporção não é tão importante nem tão difícil de conceber quanto [a que ocorre] no interior das próprias relações prático-sociais. Por exemplo, a cultura [Bildung]. Relação dos Estados Unidos com a Europa. Mas o ponto verdadeiramente difícil de discutir aqui é o de como as relações de produção, como relações jurídicas, têm um desenvolvimento desigual. Em consequência disso, p. ex., a relação do direito privado romano (nem tanto o caso no direito penal e no direito público) com a produção moderna. (MARX, 2011, p. 89-90)

Traçar uma relação imediata entre forma mercadoria e Direito pode eclipsar esta questão central. Ela, aliás, só pode ser pensada quando, ao contrário de Pachukanis ${ }^{33}$ e da

\footnotetext{
33 Diz Pachukanis sobre o tema, passando pelo Direito romano: "na verdade, tratamos nesse caso de uma forma jurídica embrionária, que ainda não desenvolveu as determinações opostas e complementares do público e do privado; por isso, o poder que carrega em si a marca das relações patriarcais e feudais caracteriza-se pela predominância do elemento teológico sobre o jurídico. A interpretação jurídica, ou seja, racionalista, do fenômeno do poder se torna possível apenas com o desenvolvimento do comércio e da economia monetária. Essas formas econômicas carregam a oposição entre vida pública e privada - oposição esta que, com o tempo, adquire um caráter de algo eterno e natural e consiste no fundamento de toda doutrina jurídica sobre o poder." (PACHUKANIS, 2017, p. 141)
} 
tradição pachukaniana, admite-se a existência de outras formas de Direito que aquela capitalista.

O desenvolvimento da produção material tem uma relação desigual com as formas políticas, jurídicas, ideológicas. As formas de objetivação dos indivíduos, como a arte e o Direito, têm suas especificidades e se relacionam com as condições materiais de produção de modo diferente. No caso do Direito, foi possível, por exemplo, que os indivíduos tomassem consciência das novas condições de produção modernas a partir do Direito privado romano. E, também por isto, é preciso que se consiga compreender o modo pelo qual nesta esfera do ser social as ideias aparecem como ideias puras de modo dúplice: ao passo que nunca podem ser, mas também na medida em que a dimensão jurídica traz certa autonomização delas. Um ponto muito difícil, segundo Marx, seria compreender como que as relações de produção, como relações jurídicas, têm um desenvolvimento desigual.

E, para isto, é necessário que a dissociação entre posse imediata das condições materiais de produção e propriedade seja vista como uma determinação central à especificidade do Direito moderno. Como mencionamos, este lado de nossa questão vem sendo deixado de lado na análise da obra marxiana. Porém, ele é de grande valor no real entendimento da crítica marxiana ao Direito.

Em verdade, conceber o Direito como uma esfera que tem por essencial a dimensão da troca é permanecer ligado a uma concepção pré-capitalista desta esfera. Pachukanis sempre enfatizou o caráter capitalista da forma jurídica; porém, é interessante notar que o essencial para sua análise, ao menos em Marx, já está presente no sujeito de troca que aparece na dissolução da comunidade romana, por exemplo. ${ }^{34}$ E, entre Roma e a moderna sociedade civilburguesa coloca-se a Idade Média.

\footnotetext{
34 Note-se que Pachukanis traz cum correlação bastante direta entre a dissolução de relações comunitárias e a implementação de relações jurídicas. Ao tratar da passagem ao modo de produção capitalista, diz o autor: "esse processo pode também ser caracterizado como uma dissolução das relações orgânicas patriarcais e sua substituição por relações jurídicas, ou seja, por relações entre sujeitos formalmente iguais perante a lei. A dissolução da família patriarcal, em que o pater familias era o proprietário da força de trabalho da esposa e dos filhos, e a conversão em uma família contratual, em que os cônjuges celebram entre si um contrato de bens, e os
} 
O desenvolvimento desigual da produção material em relação ao Direito está presente neste aspecto, em que o Direito civil romano é uma força ativa na nascente sociedade moderna. Mas a contraposição ao privilégio medieval, bem como a dissociação clara entre posse das condições materiais de produção e a propriedade jurídica passam longe das condições romanas e se identificam com as formas econômicas que se explicitam no modo de produção capitalista. A dimensão jurídica da pessoa, portanto, já está colocada, no essencial, na dissolução da comunidade romana. Mas, ao explicar esta dimensão da pessoa não se consegue compreender a crítica marxiana ao Direito. Marx trata da pessoa jurídica referindose a esta dimensão, mas a diferença específica entre a sociedade romana e a capitalista está justamente naquilo que faz com que as diversas dimensões da pessoa e do sujeito se coloquem de modo diametralmente oposto nestas sociedades. Ou seja, também por isto, não há como se ter como ponto de partida para uma crítica ao Direito a categoria sujeito de direito.

Ao se ter em conta tanto a dimensão jurídica da pessoa, trazida por Marx na categoria pessoa jurídica, quanto as trocas e a questão do desenvolvimento desigual, diz o autor sobre Roma:

No direito romano o servus é corretamente determinado como aquele que não pode adquirir nada para si pela troca (ver Institut). Por essa razão, é igualmente claro que esse direito, embora corresponda a uma situação social na qual a troca não estava de modo algum desenvolvida, pôde, entretanto, na medida em que estava desenvolvido em determinado círculo, desenvolver as determinações da pessoa jurídica, precisamente as do indivíduo da troca, e antecipar, assim, o direito da sociedade industrial (em suas determinações fundamentais); mas, sobretudo, teve de se impor como o direito da sociedade burguesa nascente perante a Idade Média. Mas seu próprio desenvolvimento coincide completamente com a dissolução da comunidade romana. (MARX, 2011, p. 299)

filhos (por exemplo, nas fazendas americanas) recebem do pai uma remuneração pelo trabalho, é um dos exemplos típicos dessa evolução. 0 desenvolvimento das relações mercantis-monetárias acelera essa evolução. A esfera da circulação, abarcada pela fórmula M-D, D-M, desempenha um papel dominante." (PACHUKANIS, 2017, p. 62-63) 
O Direito romano traz a figura do servus, que não poderia comprar nada pela troca.

E é preciso que se apontem dois aspectos logo de início: para Marx, a regulamentação do servus, colocada nos Institutos, é aquela do Direito, mesmo que não esteja presente a troca plenamente desenvolvida. Em segundo lugar, em oposição à figura jurídica do servus, aparece a pessoa jurídica, visto por Marx aqui como aquela que traz consigo as determinações do indivíduo da troca.

Estes dois aspectos são importantes para nosso tema. Eles explicitam como que, para Marx, o Direito tem uma existência em sociedades pré-capitalistas, mesmo que suas determinações na sociedade capitalista sejam muito mais complexas. A relação entre troca e a pessoa, enfatizada por Pachukanis, é vista como essencial por Marx, já que as determinações da dimensão jurídica da pessoa estão justamente no processo de troca. E, neste sentido, podemos dizer que parte essencial da compreensão marxiana sobre o Direito foi apreendida pelo autor da Teoria geral do Direito e o marxismo. Mesmo com os limites apontados acima na compreensão da pessoa e do sujeito - que Pachukanis tende a trazer de um ponto de vista muito mais jurídico do que Marx - a contribuição do jurista soviético é seminal. (Cf. SARTORI, 2015) Embora não se possa reduzir a análise marxiana da pessoa à dimensão jurídica, o essencial desta dimensão, na caracterização mais geral do Direito e da pessoa, é bem compreendido por aquele que se tornou a grande referência sobre Direito e marxismo.

Um ponto fraco da análise pachukaniana, porém, se explicita, ironicamente, na medida mesma em que ele acerta. Se o autor está correto ao relacionar a troca, a pessoa e o Direito, ele acaba por não abordar com todo o cuidado justamente aquilo que pretende: correlação entre a forma jurídica e a mercantil, que o autor diz estar plenamente desenvolvida só no capitalismo. Tal abordagem do autor acaba por não enfatizar justamente o que é importante para compreender a especificidade do Direito e do Direito burguês: sua relação desigual com a produção material, sua correlação com as formas econômicas capitalistas (mercadoria, dinheiro e capital) em suas conformações na acumulação de capital, bem como a autonomização do Direito, advinda da separação absoluta entre posse das condições materiais de produção e a propriedade privada em meio às relações jurídicas. 
Com isto, há acertos ao traçar a relação entre o Direito e a troca de mercadorias. Porém, o entendimento da esfera jurídica precisaria passar pelo papel ativo que ela tem, tanto ao se considerar a forma dinheiro na circulação quanto ao compreender a distribuição do mais-valor. Na última, a perpetuação, por meio de relações jurídicas, das desigualdades advindas das relações econômicas da moderna sociedade civil-burguesa tem seu solo. 0 desdobramento das formas econômicas é reconhecido pelo Direito da sociedade nascente do bojo da Idade Média; este Direito, porém, aparece pela primeira vez na sociedade romana em dissolução, de modo que se trata de explicar o seu desenvolvimento desigual, e que traz a especificidade das formas econômicas modernas.

O caráter desigual da relação entre o jurídico e as relações materiais, bem como a especificidade do Direito burguês precisam ser explicados com referência a estes dois processos: primeiramente, a imposição do papel ativo do Direito civil romano - em que a dimensão jurídica da pessoa aparece pela primeira vez em suas determinações essenciais diante dos privilégios medievais. Em segundo lugar, tem-se o modo pelo qual as mercadorias que se encontravam na esfera de trocas na Roma antiga são essencialmente diferentes da forma mercadoria tratada por Marx ao analisar o sistema econômico capitalista, que tem sua base no valor. Se para compreender as bases da pessoa jurídica é preciso olhar para a dimensão da troca, é de enorme importância trazer a correlação - na sociedade capitalista entre tal dimensão e a produção, distribuição, circulação e consumo. E isto implica em se enxergar o Direito, não só em meio ao movimento da forma mercadoria, mas tendo em conta suas metamorfoses, na forma dinheiro e na forma capital. Marx tratou deste tema em sua obra magna, bem como - mesmo que de modo menos sistematizado -, como pretendemos ter demonstrado, nos Grundrisse. Nesta última obra, a referência ao sujeito e à pessoa jurídicos é muito mais explícita que no livro I de $O$ capital, de que parte Pachukanis. Porém, o modo mediado pelo qual a forma mercadoria se relaciona com as formas jurídicas fica bastante claro aqui. E, assim, mesmo que o autor da Teoria geral do Direito e o marxismo apreenda corretamente aspectos do tratamento marxiano ao Direito, ele (e, em grande parte seus seguidores no Brasil) talvez deixe de abordar elementos essenciais no entendimento marxiano da especificidade do Direito no modo de produção capitalista. 


\section{REFERÊNCIAS}

ALVES, Antônio José Lopes. Marx e a analítica do capital: uma teoria das Daseinformem, Saardbrücken: Novas edições acadêmicas, 2013.

CASALINO, Vinícius. Direito e mercadoria. São Paulo: Dobra editorial, 2011.

2019.

. 0 capital como sujeito de direito. In: Direito e práxis, V. 10, n. 4. Rio de Janeiro: UERJ,

CHASIN, José. Marx: Estatuto Ontológico e Resolução Metodológica. São Paulo: Boitempo, 2009.

DUSSEL, Enrique. A produção teórica de Marx: um comentário aos Grundrisse. Trad. José Paulo Netto. São Paulo: Expressão popular, 2012.

GRESPAN, Jorge. Marx e a crítica ao modo de representação capitalista. São Paulo: Boitempo, 2019.

KASHIURA JR., Celso Naoto. Crítica da igualdade jurídica. São Paulo: Quartier Latin, 2009. . Sujeito de direito e capitalismo. São Paulo: Expressão Popular, 2014.

LUKÁCS, György. Para uma ontologia do ser social II. Trad. Nélio Schneider. São Paulo: Boitempo, 2013.

. 0 jovem Hegel. Trad. Nélio Schneider. São Paulo: Boitempo, 2018.

MARX, Karl. Grundrisse. Trad. Mario Duayer. São Paulo: Boitempo, 2011.

. Glosas marginais ao Manual de economia política de Adolph Wagner. Trad. Luiz Philipe De Caux. In: Verinotio: revista on-line de filosofia e ciências humanas, V. 23, N. 2. Rio das Ostras: UFF, 2017.

. O Capital, Livro I, Tomo I. Trad. Regis Barbosa e Flávio R. Kothe São Paulo: Nova Cultural, 1996 a.

O Capital, Livro I, Tomo II. Trad. Regis Barbosa e Flávio R. Kothe São Paulo: Nova Cultural, 1996 b.

MARX, Karl. 0 capital, livro III, tomo I. Trad. Tradução por Regis Barbosa e Flávio R. Kothe São Paulo: Nova Cultural, 1986.

MARX, Karl; ENGELS, Friedrich. Ideologia alemã. Trad. Rubens Enderle. São Paulo: Boitempo, 2007 
MASCARO, Alysson Leandro Barbate. Crise e golpe. São Paulo: Boitempo, 2018.

Filosofia do direito. São Paulo: Atlas, 2012.

NAVES, Márcio Bilharinho. Marxismo e Direito: um estudo sobre Pachukanis. Boitempo: São Paulo, 2000.

A questão do direito em Marx. São Paulo: Expressão Popular, 2014.

NEGRI, Antonio. Marx para além de Marx: ciência da crise e da subversão; caderno de trabalho sobre os Grundrisse. Trad. Bruno Cava. São Paulo: Autonomia literária, 2016.

PACHUKANIS, E. P. Teoria geral do Direito e o marxismo. Trad. Paula Vaz de Almeida. São Paulo: Boitempo, 2017.

PAÇO CUNHA, Elcemir. Considerações sobre a determinação da forma jurídica a partir da mercadoria. Crítica do Direito, n. 64. São Paulo: Mackenzie, 2014.

Do fetiche da mercadoria ao "fetiche do Direito" e de volta. In: Verinotio: Revista Online de Filosofia e Ciências Humanas, n. 19. Belo Horizonte: 2015. (Disponível em www.verinotio.org)

ROSDOLSKY, Roman. Gênese e estrutura de 0 capital. Trad. César Benjamin. Rio de Janeiro: Contraponto, 2001.

RUBIN, Isaac Illich. Teoria marxista do valor. Trad. José Bonifácio de S. Amaral Filho. São Paulo: Polis, 1987.

SARTORI, Vitor Bartoletti. Acerca da categoria de "pessoa" e de sua relação com o processo de reificação em "O capital" de Karl Marx: um debate com Pachukanis. In: Cadernos de ética e filosofia política, V 1, N 34. São Paulo: USP, 2019 a.

. ACERCA DA INDIVIDUALIDADE, DO DESENVOLVIMENTO DAS FORÇAS PRODUTIVAS E DO “ROMANTISMO” EM MARX [PARTE I]. In: Práxis comunal n. 1, v. 1. Belo Horizonte: UFMG, 2018.

. O livro II de 0 capital e o Direito: um debate com Pachukanis. In: Libertas. Juiz de Fora: UFJF, 2020 (no prelo)

. Fetichismo, transações jurídicas, socialismo vulgar e capital portador de juros: o livro III de 0 capital diante do papel ativo do Direito. Revista da Sociedade Brasileira de Economia política. Niterói: UFF, 2019 c. 
- Marx diante da revolução social na Rússia do século XIX. In: Verinotio: Revista Online de Filosofia e Ciências Humanas, n. 23, v. 1. Belo Horizonte: 2017 a <http://www.verinotio.org/conteudo/0.4443315485905218.pdf> Acesso em 05/01/2017.

Sociedades capitalistas tardias, o livro III de 0 capital e a dialética entre trabalho e as figuras econômicas concretas. In: Revista de estudos organizacionais, V. 6, N.1. Rio de Janeiro: UFF, 2019 b.

Teoria geral do Direito e o marxismo como crítica marxista ao Direito. In: Verinotio: Revista Online de Filosofia e Ciências Humanas, n. 19. Belo Horizonte: 2015. (Disponível em www.verinotio.org) 